NBER WORKING PAPER SERIES

\title{
DYNAMIC GLOBALIZATION AND ITS POTENTIALLY ALARMING PROSPECTS FOR LOW-WAGE WORKERS
}

\author{
Hans Fehr \\ Sabine Jokisch \\ Laurence J. Kotlikoff \\ Working Paper 14527 \\ http://www.nber.org/papers/w14527 \\ NATIONAL BUREAU OF ECONOMIC RESEARCH \\ 1050 Massachusetts Avenue \\ Cambridge, MA 02138 \\ December 2008
}

Research support by the Fritz Thyssen Stiftung and Netspar is gratefully acknowledged. We also thank Robert Lawrence for helpful comments. The views expressed herein are those of the author(s) and do not necessarily reflect the views of the National Bureau of Economic Research.

NBER working papers are circulated for discussion and comment purposes. They have not been peerreviewed or been subject to the review by the NBER Board of Directors that accompanies official NBER publications.

(C) 2008 by Hans Fehr, Sabine Jokisch, and Laurence J. Kotlikoff. All rights reserved. Short sections of text, not to exceed two paragraphs, may be quoted without explicit permission provided that full credit, including $(\subset$ notice, is given to the source. 
Dynamic Globalization and Its Potentially Alarming Prospects for Low-Wage Workers Hans Fehr, Sabine Jokisch, and Laurence J. Kotlikoff

NBER Working Paper No. 14527

December 2008

JEL No. F0,F20,H0,H3,J20,O0,O23

\section{ABSTRACT}

Will incomes of low and high skilled workers continue to diverge? Yes says our paper's dynamic, six-good, five-region -- U.S., Europe, N.E. Asia (Japan, Korea, Taiwan, Hong Kong), China, and India -- general equilibrium, life-cycle model.

The model predicts a near doubling of the ratio of high- to low-skilled wages over the century. Increasing wage inequality arises from a traditional source -- a rising worldwide relative supply of unskilled labor, reflecting Chinese and Indian productivity improvements. But China's and India's education policies matter. If successive Chinese and Indian cohorts become more skilled, major exacerbation of inequality will be precluded.

Hans Fehr

University of Wuerzburg

Sanderring 2

97070 Wuerzburg, Germany

hans.fehr@uni-wuerzburg.de

Sabine Jokisch

Ulm University - Institute of Economics

Helmholtzstrasse 18

D-89081 Ulm, Germany

sabine.jokisch@uni-ulm.de
Laurence J. Kotlikoff

Department of Economics

Boston University

270 Bay State Road

Boston, MA 02215

and NBER

kotlikoff@bu.edu 


\section{Introduction}

Rising income inequality is of growing concern in the U.S. and other developed countries. As Piketty and Saez (2003) and Gordon and Dew-Becker (2007) show, the top share of income received by top U.S. income decile increased from 27 percent in the 1960s percent to roughly 45 percent today. ${ }^{1}$ What explains this trend? The answer depends on who one asks. Lawrence (2008) and Gordon and Dew-Becker (2007) point to superstar agglomeration economies and CEO manipulation that has raised income inequality even within the top decile. Bound and Johnson's (1992) and Hornstein, et. al. (2005) trace diverging incomes to skill-biased technical change. Card and Di Nardo (2002) and Lemieux (2006) emphasize real reductions in the minimum wage and changes in labor force composition. And Feenstra and Hanson (1996, 1999), Sachs and Shatz (1996), and Wood (1998) point to globalization.

Resolving these differences is important. But understanding past inequality will not necessarily answer this paper's central question - how will wage inequality change in the future? To address this issue, we develop a dynamic, general equilbrium life-cycle model featuring competition among five regions -the U.S., the EMU, Northeast Asia (Japan, Korea, Taiwan, and Hong Kong), China, and India. Each of these regions produces six goods, three of which are traded. The goods are produced with capital and low-, middle-, and high-skilled labor.

The model, which pays careful attention to region-specific differences in demographics, fiscal conditions, and productivity, foresees more wage inequality over time. Indeed, it predicts a near doubling of the ratio of high- to low-skilled wage rates over the century. The source of this rising wage gap arises from a traditional source - an increase in the worldwide relative supply of unskilled labor thanks to Chinese and Indian productivity improvements. In calibrating the model, we assume that the productivity of new cohorts of workers in regions other than the U.S. catches up to the U.S. level over time. We set this catch-up period at 10 years for the EMU and Northeast Asia, 15 years for China, and 75 years for India. Once catch-up of new cohorts occurs, it takes a generation for all older worker cohorts in non-U.S. regions to be replaced by younger ones that are as productive as American workers.

New worker cohorts in a given region are assumed to enter the labor force with the same skill mix as older workers in that region. Hence, China and India, whose current work forces are disporportionately low skilled, continue to generate new worker cohorts that are disproportionately low-skilled. But as the productivity of Chinese and Indian workers, of all three skill types, rises and ultimately converges to the U.S. level, the world

\footnotetext{
${ }^{1}$ These figures are from Gordon and Dew-Becker (2007). See Hornstein, et. al. (2005), Eckstein and Nagypal (2004), and Autor, et. al. (2006, 2008) for additional evidence of rising U.S. wage inequality.
} 
experiences a major increase in its relative endowment of low-skilled, and to a lesser extent, middle-skilled workers.

These changes in relative world-wide factor endowments spell increasing wage-rate inequality. In 2005, our model's base year, the wage, measured in efficiency units, of high-skilled workers is 5.8 times higher than that of low-skilled workers. At the end of the century, it's 10.1 times higher. The ratio of the high-skilled wage rate to the middle-skilled wage rate starts at 1.9 in 2005 and ends at 2.3 in 2100.

China's and India's very high saving rates, which we assume decline gradually through time (via increases in these countries' time preference rates), help maintain a healthy world-wide ratio of capital to labor. But this fails to prevent the low-skilled wage rate, measured in efficiency units, from falling in absolute terms - by 32 percent - over the century. In contrast, the high-skilled wage rate rises by 18 percent. Middle-skilled workers see their wage rates, again measured in efficiency units, stagnate. In 2100, they are 1 percent lower than in 2005. Shutting down trade with China and India materially improves the prospects of low-skilled workers, but comes at a high economic price to developed regions' economies, whose long-run GDPs are reduced by almost 20 percent. Another casulty is the wage-rate of high-skilled workers, which end up one quarter lower than occurs with free trade.

In arguing that changes in world wide factor endowments will increasingly undermine the prospects of low- and, to a lesser extent, middle-skilled workers, we don't claim that this troubling aspect of globalization has been the dominant force raising income inequality in recent decades. As Lawrence (2008) and Gordon and Dew-Becker (2007) show, increases in the relative remuneration of the top 1 percent of earners explains much of what has been happening. Their explanations include superstar-agglomeration economies and compensation extraction by top management. Such explanations ring true, and these factors may continue to exert an influence on relative pay. But they are likely to be a side show to the main event, namely the ongoing arrival of hundreds of millions of low- and middle-skilled Chinese and Indian workers increasingly able to compete on equal terms with low- and middle-skilled workers in the developed world.

Worsening wage inequality is not, however, inevitable. If Chinese and Indian education policies limit growth in the world's relative supply of unskilled workers, the exacerbation of wage inequality can, as we show, be substantially mitigated. Indeed, if China and India end up producing workers with the same skill mix as the U.S., relative wages over the century will remain essentially unchanged. Hence, one way for the developed world to improve the lot of its low-skilled workers is to help improve China's and India's educational systems.

Our study builds on Fehr, Jokisch, and Kotlikoff (2007), which excluded India, Taiwan, 
Hong Kong, and Korea. It also posited just one good produced with capital and a one type of labor. This single labor input comprised the sum of effective units of labor supplied by workers with low, middle, and high labor-efficiency coefficients. The basic message of this earlier work is that high-saving developing regions can help low-saving developed countries maintain a high level of capital intensivity along their demographic transition paths. What that study was unable to examine, however, was how badly lowwage workers might be hurt by global trade and whether the harm to low-wage workers would worsen over time.

As before, we incorporate a rich demographic structure and model fiscal institutions in detail. Agents give birth to fractions of children at each child-bearing age, with future age-specific birth rates closely tracking government projections. After age 67, agents die randomly based on current and projected mortality probabilities. Immigration is treated as exogenous, again based on current and forecasted patterns. Each region has progressive tax and transfer benefit systems. By modifying these system, we can study how fiscal policies alter international, intergeneration, and intrageneration distributions of welfare.

Sections 2 and 3 describe, in turn, the model, calibration, and data sources. Section 4 presents baseline and alternative policy results, including shutting down trade with China and India and changing Chinese and Indian education policy, and section 5 summarizes key findings and concludes.

\section{Model}

We start with demographics and then clarify household economic behavior, firm behavior, the macroeconomic equilibrium, and fiscal institutions.

\section{Demographics}

Agents in each region live at most to age 90 . Consequently, there are 91 generations with surviving members at any point in time. The life cycle of a representative agent is described in Figure 1. Between ages 0 and 20 our agents are non-working children supported by their parents. At 21 our agents go to work and become individual households. Between ages 23 and 45 our agents give birth each year to fractions of children. An agent's first-born children (fractions of children) leave home when the parents are age 43 and the last-born leave when the agents are age 66. Our agents die between ages 68 and 90. The probability of death is 1 at age 91. Children always outlive their parents, meaning that parents always outlive grandparents. ${ }^{2}$

We denote the population vector for year $\mathrm{t}$ by $N(a, t, s, k)$, where $a=1, \ldots, 90, s=$ $23, \ldots, 45, k=1,2,3$. The term $s$ references the age of the parent at the time of birth

\footnotetext{
${ }^{2}$ If a parent reaches age 90 , his or her oldest children will be 67 . These are children who were born when the parent was age 23 .
} 
Figure 1: The individual life-cycle

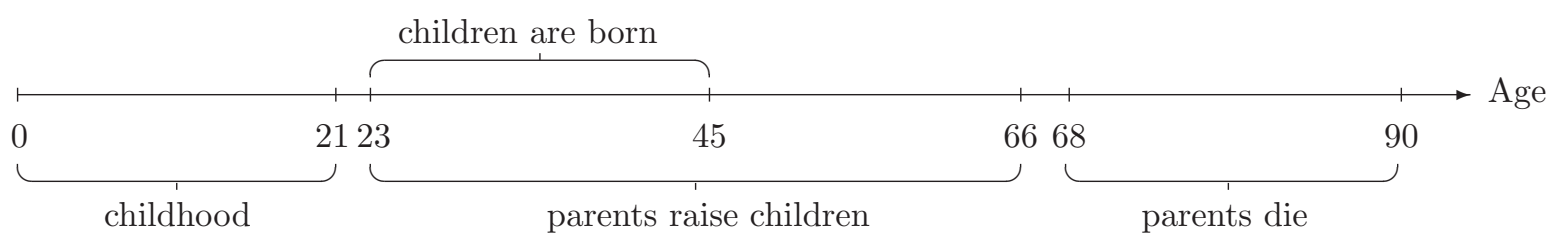

of agents age $a$ in our base year, 2005. The total number of children of an agent age $a$ with skill $k$ in year $t$ is governed by the function

$$
K I D(a, t, k)=\sum_{l=u}^{m} \frac{N(l, t, a-l, k)}{\sum_{s=23}^{45} N(a, t, s, k)} \quad 23 \leq a \leq 65, k=1,2,3,
$$

where $u=\max (0 ; a-45)$ and $m=\min (20, a-23)$. Recall that agents younger than 23 have no children and those over 65 have only adult children, i.e. $K I D(a, t, k)=0$ for $0 \leq a \leq 22$ and $66 \leq a \leq 90$. Agents between these ages have children. Take, for example, a 30 year-old agent. Such an agent has children who were born in the years $(a-l)$ since she/he was 23 . In year $t$, these children are between age $0 \leq l \leq 7$. The KID-function (1) sums the total number of children of the respective parent skill-class generation and divides it by the total number of parents of age $a$ in year $t$ who belong to skill $k$. This function takes into account that the family's age structure will change over time due to changes over time in age-specific fertility. ${ }^{3}$

Our treatment of immigration is, by necessity, simple. In each year new immigrants in each skill and age group arrive with the same number and age distribution of children and the same level of assets as natives of the identical skill and age. Once they join a native cohort, they experience the same future age-specific fertility and mortality rates as native-born agents.

\section{The Household Sector}

The model's preference structure is represented by a time-separable, nested, CES utility function. Remaining lifetime utility $U(l, t, s, k)$ of a generation age $l$ at time $t$ whose parents were age $s$ at their time of birth and who belong to skill-class $k$ takes the form

$$
U(l, t, s, k)=V(l, t, s, k)+H(l, t, s, k)
$$

where $V(l, t, s, k)$ records the agent's utility from her/his own goods and leisure consumption and $H(l, t, s, k)$ denotes the agent's utility from the consumption of her/his children.

\footnotetext{
${ }^{3}$ This approach permits the distribution of births by the ages of parents to change over time - an important improvement relative to the birthing process stipulated in Kotlikoff, Smetters and Walliser (2007).
} 
The two sub-utility functions are defined as follows:

$$
\begin{aligned}
V(l, t, s, k) & =\frac{1}{1-\frac{1}{\gamma}} \sum_{a=l}^{90}\left(\frac{1}{1+\delta}\right)^{a-l} P(a, i)\left[\bar{c}(a, i, s, k)^{1-\frac{1}{\rho}}+\varepsilon \ell(a, i, s, k)^{1-\frac{1}{\rho}}\right]^{\frac{1-\frac{1}{\gamma}}{1-\frac{1}{\rho}}} \\
H(l, t, s, k) & =\frac{1}{1-\frac{1}{\gamma}} \sum_{a=l}^{90}\left(\frac{1}{1+\delta}\right)^{a-l} P(a, i) K I D(a, i, k) \bar{c}_{K}(a, i, s, k)^{1-\frac{1}{\gamma}},
\end{aligned}
$$

where

$$
\bar{c}(a, i, s, k)=\left[\sum_{j=1}^{4} \kappa(j, a) c(j, a, i, s, k)^{\varphi}\right]^{\frac{1}{\varphi}}
$$

denotes the aggregate consumption good, while $c(j, a, i, s, k)$ and $\ell(a, i, k, s)$ denote consumption of goods $j \in\{1,2,3,4\}$ and leisure respectively, $i=t+a-l$, and $\kappa(j, a)$ defines the consumption share of good $j$ at age $a$, with $\sum_{j=1}^{4} \kappa(j, a)=1$. In permitting these shares to vary with age, our model can accommodate age-related changes in, for example, demand for medical services. The elasticity of substitution between different consumption goods $j$ is denoted by $\omega$, where $\varphi=1-\frac{1}{\omega}$. The price index $\bar{p}(a, i)$ for the aggregate consumption good $\bar{c}(a, i, s, k)$ at age $a$ in year $i$ is

$$
\bar{p}(a, i)=\left[\sum_{j=1}^{4} \kappa(j, a)^{\omega} p(j, i)^{1-\omega}\right]^{\frac{1}{1-\omega}},
$$

where $p(j, i)$ defines the consumer price of good $j$ in year $i{ }^{4}$ The children's aggregate consumption of skill-class $k$ parents who are age $a$ in period $i$ and whose parents were age $s$ at the time of their birth is defined as $\bar{c}_{K}(a, i, s, k)$, and the number of children supported by parents age $a$ is $K I D(a, i, k)$ (see equation (1)). We assume that parents apply the same consumption shares $\kappa(j, a)$ and substitution elasticities $\omega$ when they decide upon their children's consumption $c_{K}(j, a, i, s, k)$.

Since lifespan is uncertain, the utility of consumption in future periods is weighted by the survival probability of reaching age $a$ in year $i$

$$
P(a, i)=\prod_{u=l}^{a}[1-d(u, u-a+i)],
$$

which is determined by multiplying the conditional survival probabilities from year $t$ (when the agent's age is $l$ ) through year $i$. Note that $d(l, t)$ is the mortality probability of an agent age $l$ in year $t$. The parameters $\delta, \rho, \varepsilon$ and $\gamma$ represent the rate of time preference, the intratemporal elasticity of substitution between consumption and leisure,

\footnotetext{
${ }^{4}$ Note that the price index is independent of skill class since we assume identical consumption shares in each skill class.
} 
the leisure preference parameter, and the intertemporal elasticity of substitution between consumption and leisure, respectively.

Given the asset endowment a $(l, t, s, k)$ of the agent in year $t$, the lifetime budget constraint is defined by:

$$
\begin{array}{r}
\mathrm{a}(l+1, t+1, s, k)=[\mathrm{a}(l, t, s, k)+I(l, t, s, k)](1+r(t))+w(k, t) E(l, t)[h(l, t)-\ell(l, t, s, k)] \\
-T(l, t, s, k)-\bar{p}(l, t)\left[\bar{c}(l, t, s, k)+K I D(l, t, k) \bar{c}_{K}(l, t, s, k)\right], \quad(8)
\end{array}
$$

where $r(t)$ is the pre-tax return, $I(l, t, s, k)$ denotes inheritance received in year $t$. The budget incorporates our assumption that annuity markets are not operative. Instead, agents who die leave unintended bequests to their children. These children share equally in their parents' estates as well as in all the estates of other parents in the same skill group who die in that year. Thus, 50 year-olds in year $t$ whose parents were age 28 when they were born will inherit an equal share of all the assets left by 78 year-old decedents in year $t$, where the total inheritors include all children of these decedents, not just those age 50. To be precise, the inheritance of agents age $l$ in year $t$ whose parents were age $s$ at their birth are given by:

$$
I(l, t, s, k)=\frac{d(l+s, t) \bar{A}(l+s, t, k)}{\sum_{u=23}^{45} N(l+s-u, t, u, k)} .
$$

The numerator in this ratio measures the aggregate assets of skill-class $k$ parents who die in year $t$ at age $l+s$. The denominator measures the total number of children of these parents who are between ages $l+s-45$ and $l+s-23$ in year $t$. The receipt of inheritances requires us to distinguish members of each cohort according to the ages of their parents at the time the cohort members were born. The parents' ages at death determine when the children receive their inheritances. While the oldest children (born when their parents are age 23) receive their inheritances between ages 45 and 67 , the youngest (born when their parents are age 45) receive their inheritances between ages 23 and $45 .^{5}$

As in Altig, et. al. (2001) and Kotlikoff, Smetters and Walliser (2007), we model technical progress as permitting successive generations to use time more effectively, whether in working or enjoying leisure. We implement this assumption by having the time endowment of successive generations in each region grow at the common rate $\lambda$. Denote $h(a, i)$ as the time endowment of an agent age $a$ at time $i$, then

$$
h(a, i)=(1+\lambda) h(a, i-1)
$$

\footnotetext{
${ }^{5}$ Note that in providing children each year with the average inheritance left by all parents of the same age as their own parents, we avoid introducing uncertainty with respect to the amount of inheritance received each year. Hence, our model incorporates idiosyncratic uncertainty about one's date of death, but certainty with respect to what one inherits.
} 
This treatment of technical change ensures eventual convergence of the economy to a long-run steady state. Other formulations of technical change, such as making it laboraugmenting, preclude a steady state given the model's preferences. And our iterative method for determining the model's equilibrium transition path requires the terminal conditions provided by the economy's long-run steady state. ${ }^{6}$

Gross labor income of an agent in year $i$ is derived as the product of her labor supply and wage rate. The latter is the product of the skill-specific wage rate $w(k, i)$ in year $i$ and age- and year-specific earnings ability governed by:

$$
E(a, i)=\xi(i) e^{4.47+0.033(a-20)-0.00057(a-20)^{2}}(1+\lambda)^{a-21},
$$

where $i=t+a-l$. Apart from the term $\xi(i)$, this profile is taken from Auerbach and Kotlikoff (1987). Note that the higher is the rate of technological change, $\lambda$, the steeper is the age-ability profile. This captures the role of technical progress in influencing not just the level, but also the shape of longitudinal age-earnings profiles. The productivity catch-up parameter, $\xi(i)$, is region-specific. It's initially set to 0.65 in the EMU, 0.5 in NEA, 0.018 in China, and 0.01 in India, with these values chosen to match relative GDPs by region. Catch-up to the U.S. productivity level takes, as mentioned, 10 years for the EMU and NEA, 15 years for China, and 75 years for India, with the catch-up occuring linearly. Again, catch-up references the productivity new cohorts joining the workforce. In the case of China, for example, catch-up of new cohorts takes 10 years, but it takes 55 years for all Chinese workers with a given level of skill to have the same productivity as equally-skilled U.S. workers.

Net taxes, $T(l, t, s, k)$, include consumption, capital income, and progressive wage taxes as well as social security contributions net of pension, disability, and health benefits received in the form of transfer payments. Given the assumed ceiling on payroll tax contributions, payroll tax rates, both average and marginal, differ across agents. Each agent's pension benefits depend on her pre-retirement earnings history, while healthcare and disability transfers are provided on a per capita basis.

Given price indices $\bar{p}(a, i)$, interest rates $r(i)$, and wages $w(k, i)$, agents maximize utility (2) subject to the intertemporal budget constraint (8) and the constraint that leisure in each period not exceed the time endowment (i.e. $\ell(l, t, s, k) \leq h(l, t))$. They do this by choosing their leisure and consumption demands, i.e., $\ell(l, t, s, k), \bar{c}(a, i, s, k)$ and

\footnotetext{
${ }^{6}$ Note that assuming a higher rate of technical progress is isomorphic to assuming a higher rate of fertility; i.e., having more people is equivalent to having fewer people who each have more time. Since fertility rates don't enter into production functions, we circumvent the problem of steady-state incompatibility.
} 
$\bar{c}_{K}(a, i, s, k)$. Demands for specific goods $j \in\{1, \ldots, 4\}$ are, then, derived from

$$
c(j, a, i, s, k)=\left(\frac{\kappa(j, a)}{p(j, i)}\right)^{\omega} \bar{p}(a, i)^{\omega} \bar{c}(a, i, s, k) .
$$

Given individual consumption and leisure, agents' asset levels are derived from (8). Aggregate values of assets, consumption, and labor supply obey

$$
\begin{aligned}
A(t+1) & =\sum_{k=1}^{3} \sum_{a=21}^{90} \underbrace{\sum_{s=23}^{45} \mathrm{a}(a+1, t+1, s, k) N(a, t, s, k)}_{\bar{A}(a+1, t+1, k)} \\
C(j, t) & =\sum_{k=1}^{3} \sum_{a=21}^{90} \sum_{s=23}^{45}\left[c(j, a, t, s, k)+K I D(a, t, k) c_{K}(j, a, t, s, k)\right] N(a, t, s, k),(14) \\
L^{s}(k, t) & =\sum_{a=21}^{90} \sum_{s=23}^{45} E(a, t)[h(a, t)-\ell(a, t, s, k)] N(a, t, s, k) .
\end{aligned}
$$

Since households die at the beginning of each period, we aggregate across all agents alive at the end of the prior period to compute $\bar{A}(a+1, t+1, k)$, which is used in the calculation of bequests (see (9)). Total assets of agents alive at the end of period $t+1$ satisfies

$$
\mathcal{A}(t+1)=\sum_{k=1}^{3} \sum_{a=21}^{90} \sum_{s=23}^{45} \mathrm{a}(a, t+1, s, k) N(a, t+1, s, k),
$$

which includes the assets and numbers of period $t+1$ immigrants.

\section{The Production Sector}

Each region produces all six goods. Aggregate output $Y(j, t)$ of each good $j$ is produced via a Cobb-Douglas technology that uses capital $K(j, t)$ and skill-specific labor $L(k, j, t)$, i.e.,

$$
Y(j, t)=\phi K(j, t)^{\alpha(j)}\left[\prod_{k=1}^{3} L(k, j, t)^{\beta(k, j)}\right]^{1-\alpha(j)} \quad, \quad \text { for } \quad j=1, \ldots, 6
$$

where $\sum_{k=1}^{3} \beta(k, j)=1$. The parameter $\phi$ references total factor productivity, and $\alpha(j)$ and $\beta(k, j)$ denote capital's share and the share of skill-specific labor inputs in production, respectively.

Profit maximization requires

$$
\begin{aligned}
{\left[r(t)+\delta_{K}\right] K(j, t) } & =\alpha(j) q(j, t) Y(j, t) \\
w(k, t) L(k, j, t) & =[1-\alpha(j)] \beta(k, j) q(j, t) Y(j, t),
\end{aligned}
$$


where $\delta_{K}$ is the depreciation rate and $q(j, t)$ denotes the producer price of good $j$ in $t$.

\section{The Government Sector}

Each region's government issues additional debt, $\Delta B(t)$, and collect taxes to finance general government expenditures $q(6, t) C(6, t)$, those pension, healthcare, and disability benefits that are general-revenue financed, and interest on existing debt:

$$
\begin{aligned}
\Delta B(t)+\sum_{k=1}^{3} \sum_{a=21}^{90} \sum_{s=23}^{45} T(a, t, s, k) N(a, t, s, k)= \\
q(6, t) C(6, t)+\varrho^{p} P B(t)+\varrho^{h} H B(t)+\varrho^{d} D B(t)+r(t) B(t),
\end{aligned}
$$

where $\varrho^{p}, \varrho^{h}$, and $\varrho^{d}$ denote shares of these transfer payments that are financed by general revenues.

Each government maintains its initial debt-to-output ratio over time. The progressivity of wage taxation is modelled after Auerbach and Kotlikoff (1987), with marginal wage tax rates rising linearly with the wage-tax base. $P Y(t)$ defines the aggregate payroll-tax base, which differs from total labor earnings due to the ceiling on taxable wages. This ceiling is fixed at 290, 200, 150, 300, and 300 percent of average income in the U.S., EMU, NEA, China, and India, respectively. Average payroll tax rates $-\hat{\tau}^{p}, \hat{\tau}^{h}$ and $\hat{\tau}^{d}-$ for the pension, healthcare, and disability transfer programs are determined based on each region's transfer-program-specific budget, taking into account general revenue finance, i.e.

$$
\begin{aligned}
\hat{\tau}^{p}(t) P Y(t)=\left(1-\varrho^{p}\right) P B(t), \quad \hat{\tau}^{h}(t) P Y(t)=\left(1-\varrho^{h}\right) H B(t), & \\
& \hat{\tau}^{d}(t) P Y(t)=\left(1-\varrho^{d}\right) D B(t),
\end{aligned}
$$

where $P B(t), H B(t)$ and $D B(t)$ are total outlays of the pension, health care, and disability systems, respectively. In China and India disability insurance provisions is handled by state pension systems and these systems don't separate disability and pension payments in their reporting. Hence, for these countries, the disabilty benefit payroll tax rate is set to zero, and the pension benefit payroll tax rate finances both types of benefits.

Due to contribution ceilings, individual pension, disability, and health-insurance payrolltax rates can differ from the average payroll tax rate. Above the contribution ceiling, marginal social security contributions are zero and average social security contributions fall with the agent's income. To accommodate this non-convexity in the budget constraint, we assume that the highest earnings class in each region pays pension payroll taxes and, in the EMU, NEA, China and India, health-insurance payroll taxes, up to the relevant ceilings, but face no payroll taxation at the margin. The other earnings classes are assumed to face the full statutory tax rate on all their earnings. The disability payroll 
taxes in the U.S., the EMU and NEA are modeled in an equivalent manner. However, since there is no ceiling on U.S. Medicare taxes, all skill groups in the U.S. face the health-insurance payroll tax at the margin.

If a $k$-skill class agent, whose parents were $s$ years old at his birth, retired in year $i$ at the exogenously set retirement age $\bar{a}(i)$, her pension benefit $\operatorname{Pen}(a, t, s, k)$ in year $t \geq i$ when she is age $a \geq \bar{a}(i)$ is assumed to depend linearly on her average earnings during her working life $\bar{W}(i, s, k)$ :

$$
\operatorname{Pen}(a, t, s, k)=\nu_{0}+\nu_{1} \times \bar{W}(i, s, k) .
$$

The region-specific parameters $\nu_{0}, \nu_{1}$ for the U.S., the EMU and NEA were chosen to match replacement rates reported in OECD (2007c). In China and India, only a fraction of public employees are covered by the public pension system. But spending on civil service pensions in China and India amounts to 2-3 percent of GDP (see James 2002 and World Bank 2005). Since we cannot distinguish between covered and non-covered employment in our model, we assume a pension-replacement rate of 40 percent of average pre-retirement earnings. The rate is far too low for covered employees and far too high for non-covered employees, but it results in realistic aggregate pension expenditures in the two countries.

General government expenditures $q(6, t) C(6, t)$ consist of government purchases of goods and services, including educational expenditures and health outlays. Over the transition, the ratio of general government purchases of goods and services to GDP is held fixed. Age-specific per-capita education and disability outlays are assumed to grow with GDP per capita over the transition.

Age-specific health outlays per capita also grow with GDP per capita. However, in the U.S., EMU, and Japan we assume an additional growth rate of 2.0 percent per year during the first 20 years of the transition and of 1.0 percent between 2025 and $2035 .^{7}$ In China and India, age-specific healthcare outlays per capita are assumed to grow at a faster pace: During the first 40 years of the transition there is an additional annual growth rate of four percent. Note that while we treat 80 percent of health benefits as government consumption and 20 percent as fungible transfers to households, disability benefits are modeled exclusively as fungible transfers to households.

During the transition, we keep the ratio of wage-tax to consumption-tax revenue fixed each year and balance the government's annual budget (20) by adjusting the intercept in our linear equation determining the average wage-tax rate as well as the consumption-tax rate.

\footnotetext{
${ }^{7}$ As shown in Hagist and Kotlikoff (2009), this is a rather conservative assumption concerning future growth in benefit levels.
} 


\section{Computing the Economy's Dynamic Equilibrium}

To compute the world economy's perfect-foresight general equilibrium transition path, we start with initial guesses of the equilibrium factor and product prices of $r(t), w(k, t)$, $q(j, t)$. We next use these prices to determine consumption demands, $C(j, t, z)$ and supplies of both labor, $L^{s}(k, t, z)$ and assets, $A(t+1, z)$ for each year in each region $z$. We assume that consumption goods $j=1,2$ as well as the public good $j=6$ are non-traded goods and that consumption goods $j=3,4$ as well as the investment good $j=5$ are traded. Equilibrium in the traded goods market requires that world output equals world demand

$$
\begin{gathered}
Y_{W}(j, t)=\sum_{z \in W} C(j, t, z) \quad j=3,4 \\
Y_{W}(5, t)=(1+n) \sum_{z \in W}[A(t+1, z)-B(t+1, z)]-(1-\delta) \sum_{z \in W}[\mathcal{A}(t, z)-B(t, z)]
\end{gathered}
$$

where $Y_{W}(j, t)$ stands for total worldwide production of good $j$ in year $t$ and $z$ references a region in the set $W=\{\mathrm{U} . \mathrm{S} ., \mathrm{EMU}, \mathrm{NEA}$, China, India $\}$. Note that world output of the investment good is the difference between the world capital stock in $t+1$ and $t$, which, in turn, is the difference between world wealth at $t+1$ and $t$.

The time $t$ world-wide supply of assets, $A_{W}(t)$, and world-wide labor supply of skill $k$, $L_{W}^{s}(k, t)$, satisfy

$$
\begin{aligned}
A_{W}(t) & =\sum_{z \in W} \mathcal{A}(t, z) \\
L_{W}^{s}(k, t) & =\sum_{z \in W} L^{s}(k, t, z) .
\end{aligned}
$$

Factor demands in the non-traded sectors $j \in\{1,2,6\}$ in each region $z$ are determined by the first-order conditions

$$
\begin{aligned}
K(j, t, z) & =\frac{\alpha(j) q(j, t)}{r(t)+\delta_{K}} C(j, t, z) \\
L(k, j, t, z) & =\frac{[1-\alpha(j)] \beta(k, j) q(j, t)}{w(k, t)} C(j, t, z) .
\end{aligned}
$$

World factor markets must satisfy

$$
\begin{aligned}
& \tilde{L}_{W}^{s}(k, t)=L_{W}^{s}(k, t)-\sum_{z \in W}\left(\sum_{j=1}^{2} L(k, j, t, z)+L(k, 6, t, z)\right)=\sum_{j=3}^{5} \theta_{L}(k, j, t) Y_{W}(j, t) \\
& \tilde{A}_{W}(t)=A_{W}(t)-\sum_{z \in W}\left(\sum_{j=1}^{2} K(j, t, z)+K(6, t, z)+B(t, z)\right)=\sum_{j=3}^{5} \theta_{K}(j, t) Y_{W}(j, t)
\end{aligned}
$$


with $\theta_{L}(k, j, t)=\frac{L(k, j, t)}{Y_{W}(j, t)}$ referencing labor of skill type $k$ per unit of output of good $j$, in year $t, \theta_{K}(j, t)=\frac{K(j, t)}{Y_{W}(j, t)}$ referencing capital per unit of output of good $j$, in year $t$, and $\tilde{L}_{W}^{s}(k, t)$ and $\tilde{A}_{W}(t)$ referencing, respectively, the world-wide excess supplies of labor and capital available for productive use in the traded sectors given the world-wide demands for these factors to produce non-traded goods. The second equalities in the above two equations state that the excess supplies of inputs available to produce traded goods must equal their respective world-wide demands by traded goods producers.

Substituting (19) into (29) and (18) into (30) leads to the capital and labor input-output coefficients in the investment good sector for every period $t$ from

$$
\begin{aligned}
\theta_{L}(k, 5, t) & =\left[\sum_{j=3}^{5} \frac{[1-\alpha(j)] \beta(k, j) q(j, t)}{[1-\alpha(5)] \beta(k, 5) q(5, t)} Y_{W}(j, t)\right]^{-1} \tilde{L}_{W}^{s}(k, t) \\
\theta_{K}(5, t) & =\left[\sum_{j=3}^{5} \frac{\alpha(j) q(j, t)}{\alpha(5) q(5, t)} Y_{W}(j, t)\right]^{-1} \tilde{A}_{W}(t) .
\end{aligned}
$$

The producer price of the investment good is normalized to unity, i.e. $q(5, t)=1.0$. This permits us to calculate the value of $\phi$ from the first-order condition for wage rates (equation (19)) so that the wage rate of U.S. unskilled workers is normalized to unity in the first period.

Next, we update our guesses of wages and interest rates by inverting (18) and (19)

$$
\begin{aligned}
r(t) & =\frac{\alpha(5)}{\theta_{K}(5, t)}-\delta_{K} \\
w(k, t) & =\frac{(1-\alpha(5)) \beta(k, 5)}{\theta_{L}(k, 5, t)} .
\end{aligned}
$$

In order to derive producer prices $q(j, t)$ for private and public consumption goods we first compute the respective capital and labor input-output coefficients, $\theta_{K}(j, t)$ and $\theta_{L}(k, j, t)$. Substituting the two first-order conditions (18) and (19) into the per-unit demand functions for capital and income-class specific labor we derive, after rearranging,

$$
\begin{gathered}
\theta_{K}(j, t)=\frac{1}{\phi} \frac{\alpha(j)}{r(t)+\delta_{K}}\left(\frac{r(t)+\delta_{K}}{\alpha(j)}\right)^{\alpha(j)} \prod_{k=1}^{3}\left(\frac{w(k, t)}{[1-\alpha(j)] \beta(k, j)}\right)^{[1-\alpha(j)] \beta(k, j)} \\
\theta_{L}(k, j, t)=\frac{1}{\phi} \frac{[1-\alpha(j)] \beta(k, j)}{w(k, t)}\left(\frac{r(t)+\delta_{K}}{\alpha(j)}\right)^{\alpha(j)} \prod_{k=1}^{3}\left(\frac{w(k, t)}{[1-\alpha(j)] \beta(k, j)}\right)^{[1-\alpha(j)] \beta(k, j)} .
\end{gathered}
$$


The new producer prices for goods $j \in\{1,2,3,4,6\}$ are now computed from

$$
q(j, t)=\left[r(t)+\delta_{K}\right] \theta_{K}(j, t)+\sum_{k=1}^{3} w(k, t) \theta_{L}(k, j, t),
$$

which measures the unit cost of production as the product of input prices and their usage per unit of output.

We next use the factor input-output ratios and the total output of traded goods to allocate production to the different regions. Doing so lets us determine the regional pattern of net exports. Our procedure is to first derive, for each year $t$ and every productivity level $k$, the excess labor supply $\tilde{L}^{s}(k, t, z)$ in region $z$ available for use in traded goods. We then relate these excess labor supplies to their respective excess labor demands; in so doing, we arrive at three equations in three unknowns, which we use to determine the share of worldwide production of each of the traded goods that occurs in region $z$.

Equation (38) below states that traded-goods excess labor supplies of each skill type at time $t$ in region $z$ (the right-hand side of the equation) equals the sum over the three traded goods of the product of three variables - the input-output coefficient for the type of labor and traded good being considered, the world-wide supply of that traded good, and the share of world-wide supply of that traded good, $\theta_{Y}(j, t, z)$, that is being produced in region $z$.

$$
\left(\begin{array}{lll}
\theta_{L}(1,3, t) Y_{W}(3, t) & \theta_{L}(1,4, t) Y_{W}(4, t) & \theta_{L}(1,5, t) Y_{W}(5, t) \\
\theta_{L}(2,3, t) Y_{W}(3, t) & \theta_{L}(2,4, t) Y_{W}(4, t) & \theta_{L}(2,5, t) Y_{W}(5, t) \\
\theta_{L}(3,3, t) Y_{W}(3, t) & \theta_{L}(3,4, t) Y_{W}(4, t) & \theta_{L}(3,5, t) Y_{W}(5, t)
\end{array}\right) \times\left(\begin{array}{c}
\theta_{Y}(3, t, z) \\
\theta_{Y}(4, t, z) \\
\theta_{Y}(5, t, z)
\end{array}\right)=\left(\begin{array}{l}
\tilde{L}^{s}(1, t, z) \\
\tilde{L}^{s}(2, t, z) \\
\tilde{L}^{s}(3, t, z)
\end{array}\right)
$$

Equation (38) represents three equations in the three unknowns $\theta_{Y}(3, t, z), \theta_{Y}(4, t, z)$, and $\theta_{Y}(5, t, z)$. Given values of these three variables, we can determine factor inputs in the traded goods sectors from

$$
\begin{aligned}
L(k, j, t, z) & =\theta_{Y}(j, t, z) \theta_{L}(k, j, t) Y_{W}(j, t) \quad \text { and } \\
K(j, t, z) & =\theta_{Y}(j, t, z) \theta_{K}(j, t) Y_{W}(j, t) . \quad j \in\{3,4,5\}
\end{aligned}
$$

Note that nothing precludes our calculating negative values for the $\theta_{Y}(j, t, z) \mathrm{s}$. Negative values are, of course, infeasible and indicative of specialization. Recall that our model features three immobile factors of production (the three labor skill groups), one mobile factor (capital), and three traded goods. These elements suffice for non-specialization and factor-price equalization, but they don't guarantee this outcome. As in the standard 2 by 2 trade model, if relative factor endowments are sufficiently distinct (e.g., one region has zero supply of a particular factor), specialization will arise and factor prices will not 
be equalized.

In our model, which features exogenous net immigration, we could modify our assumed skill-specific time paths of net immigration to restore factor prize equalization were it otherwise fail to arise. But making such assumptions would be at odds with prevailing immigration policy. An alternative and, actually, highly realistic way to restore, where needed, factor price equalization via factor mobility is to take into account the fact that domestic firms are now routinely employing offshore labor (e.g., software engineers, customer support representatives, telephone salespeople) to participate in their domestic productive processes via the internet and telephone. Such foreign employees are, in fact, working with the domestic firm's domestic employees as well as domestic capital in producing domestic output.

To accommodate this economic reality, we set up the following iteration. We set any negative output shares computed via equation (38) to zero and compute, using the remaining positive output shares, an updated and, of course, higher labor demand for each skill level in each region $z$. The difference, for each skill group, between total excess labor demand and total excess labor supply in the traded goods sector of region $z$ is assumed to be acquired via offshore hires. We secure this skill-specific offshore labor by reducing the excess labor supplies for that skill group across the other four regions. The region-specific reductions are allocated in proportion to each of the relevant regions' shares of worldwide labor supply of the skill group in question. Given this resulting modification of excess labor supplies in the traded goods sector in each region, we then recalculate the output shares $\theta_{Y}(j, t, z)$ and continue iterating in this fashion until all output shares are either positive or zero.

Clearly, other assumptions about the locus of offshore labor hires would result in different region-specific loci of world production. But they would not change the world (five-region) equilibrium transition path. This is just Rybczynski's Theorem (1955) in action; with complete factor mobility, one can't say anything about where products will be produced, although one can say everything about what will be produced and who will get paid what for that production. Of course, the world does not feature complete factor mobility. Our assumption is that the world (our five regions) has only enough factor mobility, including the hiring of labor offshore, to achieve factor-price equalization. We believe our assumption about where the offshore labor is located is reasonable and that the resulting region-specific GDPs, which rely (positively and negatively) on offshore labor, are realistic.

Our algorithm iterates until the time paths of interest and wage rates converge to a fixed point and supplies for each good equals its demand. We give our economy 300 years to reach to a steady state. In fact, our model reaches a steady state to many decimal places 
decades prior to year 300. It also converges very tightly around the equilibrium transition path.

\section{Calibration}

\section{Population projections}

This section describes our data set for the benchmark population in the year 2000 and the transition. ${ }^{8}$ The main data source for our population data is the medium variant of the United Nations population projections (UNPD, 2007). In the case of Taiwan we had to rely on national population statistics provided by the Statistical Office (CEPD, 2007). However, part of the raw data was only supplied in aggregates. In addition, the specific structure of our population model imposed certain restrictions on our data set.

To specify the current and future demographic structure of each region we start with year2000 age-specific population $[\bar{N}(a, 2000)]$ and age-specific net-immigration $[\overline{N M}(a, 2000)]$ counts. In constructing existing as well as future age-population counts, we have to link each initial cohort between the ages of 1 and 68 to those of their parents who are still alive. The reason is that children receive bequests from their parents, and the levels and timing of these inheritances depend on the ages of their parents. This linkage is achieved by applying past fertility rates to each cohort under age 69 in year 2000. If, for example, 15 percent of the parents of newborns in 1980 were 25 years old, then 15 percent of the 20-year-old's in year 2000 are assigned to parents age 45 .

In addition, each cohort is split into three skill classes $k$. According to the latest figures on educational attainment from the U.S. Census Bureau (2008), 15 percent of each cohort belong to the lowest skill class, 30 percent to the top skill class, and the remaining 55 percent to the middle skill class in the U.S., EMU and NEA. Since there are no available data detailing educational attainment in China and India, we assume that 22 percent of the overall population belong to the lowest, 25 percent to the top skill class, and 53 percent to the middle. ${ }^{9}$

To determine the evolution of the population in each region over time, we applied region-, age-, and year-specific mortality and fertility rates to the cohorts alive in year 2000 as well as to their children as they reach their ages of fertility and mortality. In the baseline path the exogenous current and future mortality and fertility rates follow the medium variant of the United Nations population projection (UNPD, 2007) for the U.S., EMU, NEA, China and India.

According to this projection, mortality rates will decline in all regions over time. Consider Northeast Asia whose 2005 life expectancy at birth equaled 81.2. According to official

\footnotetext{
${ }^{8}$ Although the economic model starts in year 2005, we chose year 2000 as the initial year for the population projections due to data availability.

${ }^{9}$ This assumption may well understate the relative number of unskilled workers in the two countries.
} 
projections, NEA's life expectancy in 2050 will reach 86.7. Due to the high life expectancy of Japan, NEA's citizens now have a 3 year higher life expectancy than Americans and a 1.5 higher life expectancy than EMU citizens. In China, life expectancy is now 8.3 years lower than in Japan. In India it is 16.5 years lower. According to the UN projections, NEA countries will continue to maintain their longevity lead through time. Only India will reduce the gap significantly to 11.1 years in the next half decade. Table 1 shows our agent's life expectancies at birth in the baseline path, which is kept constant after year 2050. The respective numbers are higher than the actual values, since our model's agents don't die prior to age 68 .

Total fertility rates currently equal 2.05, 1.5, 1.53, 1.73 and 2.8 in the U.S., EMU, NEA, China, and India, respectively. Nevertheless the United Nations expects fertility rates in all regions to converge to 1.85 children by $2050 .{ }^{10}$ This path of fertility rates is also shown in Table 1. In the baseline path, we assume annual net immigration of 1 million per year in the U.S., 450,000 in the EMU, and 54,000 in NEA. Net immigration into China and India is negative. In accordance with UN projections, the number of net emigrants is fixed at its current value of 390,000 people per year in China and 280,000 people in India.

Given the population age structure in year 2000 as well as projected future fertility, mortality, and net immigration rates, we compute the population vector $N(a, t, s, k)$ for the years $t$ between 2001 and 2050. After year 2050, fertility rates are endogenously adjusted in line with zero population growth and a stable population age structure. Since the net immigration rate is positive in the U.S., the EMU, and NEA, the populationstabilizing post-2050 fertility rates are below 2.0. Equivalently, the fertility rates in China and India are set above 2.0 after 2050 due to positive net emigration rates.

Table 1 also shows projected changes over time in total populations and population age structures. Due to high fertility and net immigration, the U.S. population is projected to increase from 293 million in 2005 to 445 million in 2100. In the EMU, the population falls over the century from 309 to 288 million. In Northeast Asia, the population falls from 204 million to 130 million. The Chinese population decreases by even more - from roughly 1.30 billion to 1.15 billion. In contrast, the population in India increases from 1.13 billion in 2005 to 1.5 billion in 2100 ; i.e., India becomes the most populous country in the world.

As one would expect, the population share of those 65 and older increases in all five regions. There are, however, major differences in the aging process across the regions. First, whereas the share of the working-age population increases in India until 2050, it decreases modestly in the U.S., but more substantially in the EMU, China and NEA. Second, the share of elderly increases to a much larger extent in Japan and China compared to India,

\footnotetext{
${ }^{10}$ The different projection in NEA is due to Taiwan which assumes a different fertility pattern in the future.
} 
the EMU, and the U.S. Table 1 indicates that our model's demographic machinery does a remarkably good job matching official projections for the five regions both with respect to the absolute number and age compositions of their respective populations.

Table 1: Comparing Actual and Simulated Population Projections

\begin{tabular}{|c|c|c|c|c|c|c|c|c|c|c|}
\hline \multirow{2}{*}{$\begin{array}{l}\text { Country } \\
\text { Year }\end{array}$} & \multicolumn{2}{|c|}{ U.S. } & \multicolumn{2}{|c|}{ EMU } & \multicolumn{2}{|c|}{ NEA } & \multicolumn{2}{|c|}{ China } & \multicolumn{2}{|c|}{ India } \\
\hline & 2005 & 2050 & 2005 & 2050 & 2005 & 2050 & 2005 & 2050 & 2005 & 2050 \\
\hline \multicolumn{11}{|c|}{ Fertility Rate } \\
\hline Model & 2.08 & 1.85 & 1.49 & 1.82 & 1.53 & 1.75 & 1.64 & 1.85 & 2.99 & 1.85 \\
\hline Official & 2.05 & 1.85 & 1.50 & 1.85 & 1.53 & 1.73 & 1.73 & 1.85 & 2.81 & 1.85 \\
\hline \multicolumn{11}{|c|}{ Life Expectancy at Birth } \\
\hline Model & 81.9 & 83.8 & 82.4 & 84.6 & 84.2 & 87.3 & 76.2 & 80.2 & 63.9 & 75.3 \\
\hline Official & 78.2 & 73.1 & 79.7 & 84.3 & 81.2 & 86.7 & 73.0 & 79.3 & 64.7 & 75.6 \\
\hline \multicolumn{11}{|c|}{ Total Population (in Millions) } \\
\hline Model & 293.9 & 403.6 & 309.5 & 308.3 & 205.4 & 181.4 & 1228.1 & 1401.5 & 1129.9 & 1643.9 \\
\hline Official & 299.8 & 402.4 & 312.2 & 312.9 & 205.6 & 172.6 & 1313.0 & 1408.8 & 1134.4 & 1658.3 \\
\hline \multicolumn{11}{|c|}{$\begin{array}{l}\text { Age Structure (in Percent of total Population) } \\
0-15 \text { Years }\end{array}$} \\
\hline Model & 20.7 & 17.8 & 16.1 & 15.0 & 14.6 & 13.7 & 21.6 & 16.3 & 33.2 & 18.2 \\
\hline Official & 20.8 & 17.3 & 15.6 & 14.5 & 15.5 & 10.7 & 21.6 & 15.3 & 33.0 & 18.2 \\
\hline \multicolumn{11}{|c|}{ 15-64 Years } \\
\hline Model & 67.2 & 62.0 & 67.1 & 57.5 & 65.8 & 53.1 & 71.8 & 61.6 & 62.4 & 66.1 \\
\hline Official & 66.9 & 61.7 & 66.8 & 55.9 & 68.5 & 52.6 & 70.7 & 61.0 & 62.0 & 67.3 \\
\hline \multicolumn{11}{|c|}{$65-90$ Years } \\
\hline Model & 12.1 & 20.1 & 16.8 & 27.5 & 19.5 & 33.2 & 6.6 & 22.0 & 4.4 & 15.7 \\
\hline Official & 12.3 & 21.0 & 17.6 & 29.6 & 16.0 & 36.7 & 7.7 & 23.7 & 5.0 & 14.5 \\
\hline
\end{tabular}

\section{Specifying Our Six Products}

Our aggregation of goods into four consumption goods (services, housing, low tech, and high tech), an investment good, and a public good and is based on the March 2007 release of the EU-KLEMS database ${ }^{11}$. This database reports the total values of capital

\footnotetext{
${ }^{11}$ See Timmer et al. (2007). Services includes distribution and personal services. Housing includes construction and real estate activities. Low-tech consumption includes consumer manufacturing, agriculture, hunting, forestry, and fishing. High-tech consumption includes electrical and optical equipment, wood products, coke, petroleum, and nuclear fuel products, mining, electricity, gas, and water supply, post and telecommunications, and finance and business. Investment includes machinery, transport equipment, chemical products, rubber and plastic products, non-metallic mineral products, and basic metals
} 
and labor inputs for 26 different production sectors as well as the shares of high-skilled, medium-skilled and low-skilled labor in total labor inputs. The annual data base covers most OECD countries as well as various country groups during the period 1970-2004.

Given this sectoral aggregation, we computed the capital income shares as well as the skill-specific labor shares from the 2004 (SIC based) U.S. data as reported in Table 2. As one would expect, capital income shares are especially high in the housing sector; they are especially low in the private service and public goods sectors. Note that with the exception of housing our capital shares accord closely with the sector capital shares reported in Valentinyi and Herrendorf (2008). ${ }^{12}$ As indicated in the table, the low-tech consumption good and housing sectors have the highest shares of low-skilled labor; the high-tech consumption good sector, the non-housing services sector, and the public good sector have the highest share of high-skilled labor. Finally, the depreciation rate is set at the same rate for all countries.

Table 2: Production Technology Parameters

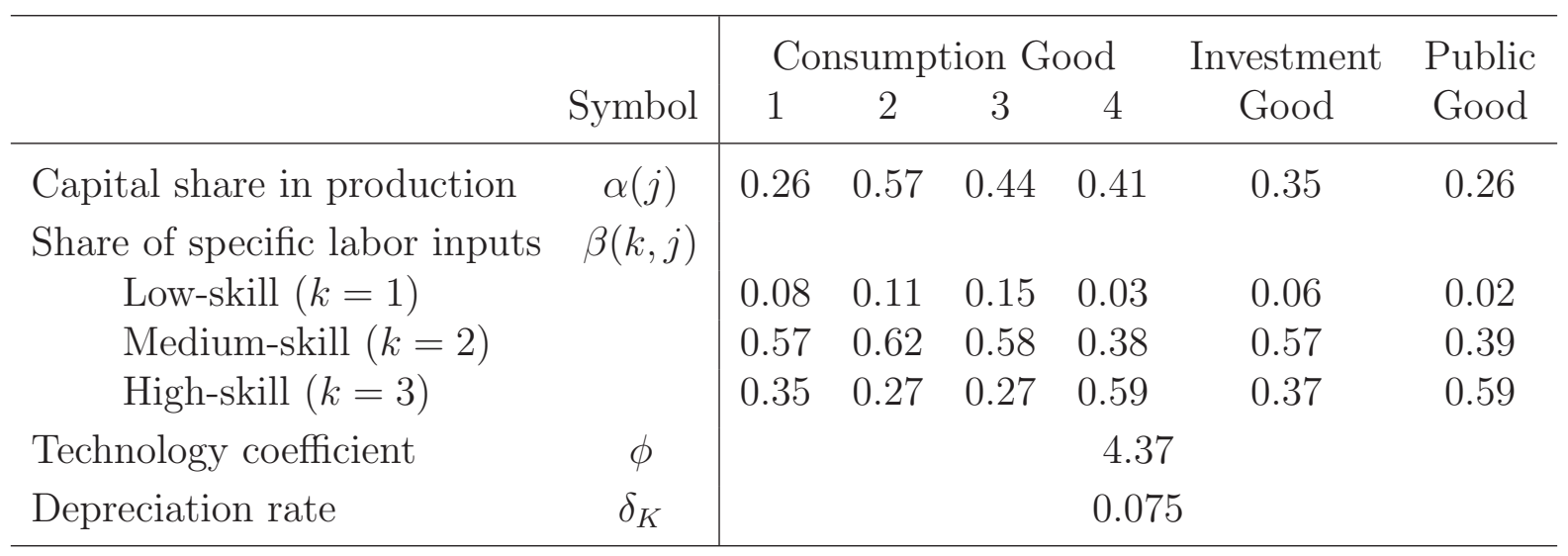

Table 3 reports values of preference and policy parameters. The time-preference rates in the five regions were set to match the model's 2005 ratios of private consumption to GDP to the region-specific values reported in European Commission (2008) for the U.S., EMU, and NEA ${ }^{13}$, European Commission (2007) for China, and OECD (2007e) for India. The U.S., EMU, and NEA time-preference rates are held fixed through time. But in line with our baseline assumption that the Chinese and Indian public will eventually adopt developed economies' spending habits, we gradually raise the time preference rate of successive Chinese and Indian cohorts so that the cohorts that reach adulthood (age 21) in 2030 and thereafter have the same time-invariant time-preference rate as in the

and fabricated metal products. Public goods includes public administration, education, and health.

${ }^{12}$ Their housing sector is confined to construction, whereas our housing sector is meant to include imputed rent from housing services.

${ }^{13}$ Note that all macroeconomic values for NEA are compared to official data reported for Japan. 
U.S. The intertemporal elasticity of substitution, the elasticity of substitution between consumption and leisure, and the leisure preference parameters are taken from Kotlikoff, Smetters, and Walliser (2007). The elasticity of substitution between consumption goods was chosen to generate a pattern of demand that accords with U.S. consumption data. The age-specific weights of the different consumption goods in the utility function are derived from U.S. Department of Labor (2007), where we aggregated the different consumption goods reported there according to our table 2 classification. Note that the consumption shares vary significantly with age, with housing's share rising considerably with age.

Table 3: Preference, Productivity and Policy Parameters

\begin{tabular}{|c|c|c|c|c|c|c|}
\hline & Symbol & U.S. & EMU & NEA & China & India \\
\hline Time preference rate & $\delta$ & 0.02 & 0.02 & 0.02 & -0.10 & -0.04 \\
\hline Intertemporal elasticity of substitution & $\gamma$ & & & 0.25 & & \\
\hline $\begin{array}{l}\text { Intratemporal elasticity of substitution } \\
\text {-between consumption and leisure } \\
\text {-between consumption goods }\end{array}$ & $\begin{array}{l}\rho \\
\omega\end{array}$ & & & $\begin{array}{l}0.4 \\
1.1\end{array}$ & & \\
\hline Leisure preference parameter & $\varepsilon$ & & & 1.5 & & \\
\hline $\begin{array}{l}\text { Consumption shares of goods } j \\
\qquad \begin{aligned} & a<25 \\
25 \leq & a \leq 34 \\
35 \leq & a \leq 44 \\
45 \leq & a \leq 54 \\
55 \leq & a \leq 64 \\
65 \leq & a \leq 74 \\
& a \geq 75\end{aligned}\end{array}$ & $\kappa(j, a)$ & & $\begin{array}{l}1 \\
0.04 \\
0.06 \\
0.07 \\
0.08 \\
0.11 \\
0.16 \\
0.21\end{array}$ & $\begin{array}{cc}2 & 3 \\
0.36 & 0.19 \\
0.40 & 0.17 \\
0.40 & 0.18 \\
0.38 & 0.17 \\
0.38 & 0.17 \\
0.38 & 0.16 \\
0.40 & 0.15\end{array}$ & $\begin{array}{ll} & 4 \\
9 & 0.41 \\
7 & 0.37 \\
8 & 0.35 \\
7 & 0.37 \\
7 & 0.34 \\
6 & 0.30 \\
5 & 0.24\end{array}$ & \\
\hline Shift parameter for productivity & $\xi$ & 1.00 & 0.65 & 0.50 & 0.018 & 0.01 \\
\hline Technical progress & $\lambda$ & & & 0.01 & & \\
\hline Capital tax rate (in \%) & $\tau^{r}$ & 11.0 & 14.0 & 8.0 & 3.0 & 3.0 \\
\hline Debt (in \% of national income) & $B / Y$ & 43.4 & 50.3 & 70.0 & 23.5 & 60.0 \\
\hline Age of retirement & $\bar{a}$ & 63 & 60 & 60 & 60 & 60 \\
\hline
\end{tabular}

We normalize the labor productivity parameter $-\xi$ - at 1 for the U.S. and set the initial values of this parameter for the other four regions to match the 2005 relative values of GDP. In the non-U.S. region, this parameter is gradually raised to 1.0 (the U.S. value) for each successive cohort of new worker cohorts. For the EMU and NEA we assume this adjustments occurs over the 10 years between 2005 and 2015. For China we assume it takes 15 years. And for India, we assume 75 years. This assumption concerning India is in line with Bosworth and Collins (2008) who found that during the last four decades 
India made little progress in increasing even elementary educational attainment. Once this phase-in period is complete, it takes another 40 years until all cohorts of workers in the non-U.S. regions have the same value, namely 1 , of $\xi$ entering in the determination of their labor productivity as determined by (11).

It may be useful, at this point, to point out that there are five different factors involved in the determination of a worker's total labor earnings in a given year. The first is the worker's effective time endowment, which, as indicated above, depends on when the worker is born and on the rate of technical change. The second is the share of the worker's effective time endowment that she chooses to allocate to working, rather than to leisure. The third is the labor-productivity coefficient, $\xi$, just mentioned. The fourth is the remaining elements in (11), which capture how productivity changes with the worker's age and, therefore, depend on the worker's age. And the fifth is the equilibrium wage rate per effective unit of labor supply for the worker's skill group.

The model's debt-to-GDP levels were set based on OECD (2007a) reports of net government liabilties for the U.S., EMU, and NEA, an OECD (2005) report of gross debt for China, and an IMF (2005) report of gross debt for India. During the transition debtto-GDP ratios are assumed to remain unchanged. The maximum ages of retirement are taken from OECD (2006a) for the U.S. and EMU and from SSA (2007) for NEA, China, and India. We calibrated the endogenous consumption and wage tax rates and set the personal capital income tax rates in order to yield the structure of indirect and direct tax revenues reported in European Commission (2008) for the U.S., the EMU, and NEA and in OECD (2002) and Poirson (2006) for China and India. Our wage tax systems are assumed to be progressive, with the parameters of each region's tax system set to generate what appears to be realistic average and marginal tax rates.

In calibrating health expenditures in our model, we apply the Japanese age-specific government healthcare expenditure profile for NEA as well as China and India. In the case of the EMU, we use the German profile. For the U.S. our profile comes from Hagist and Kotlikoff (2009). We assume uniform disability expenditures by age for ages between 21 and 64 in the U.S., the EMU, and NEA. We don't model separate disability programs for China and India. In the case of the U.S., EMU, and NEA, total social insurance outlays for pensions, disability, and health, measured as a share of GDP are set to accord with the values reported in OECD (2007b, c, d). In calibrating social security contribution rates, we assume that 75 percent of overall healthcare benefits in the U.S. and 25 percent in NEA are financed by general taxes. In the EMU, we assume that 20 percent of the outlays of all three social security systems (health, pension, disability) are financed by general taxes. Note that our baseline path assumes a gradual 20 percent cut in NEA pension replacement rates through 2017 in accord with recent pension reforms in Japan. For China our division of social insurance outlays is restricted to pensions plus disability 
payments; for India we assume that social insurance outlays are spent soley on health expenditures. Calibration of social insurance outlays here is based on OECD (2005) for China. Since data on India were not available we assumed the same values as for China. We use the German age-specific education profile (due to data availability) for all regions in the model and rescale it to get realistic education outlays in year 2005 in each region (see below). In addition to these parameter values, our model requires an initial distribution of assets by age and income class for each region. These profiles are region-specific and were adopted from a steady-state run of our simulation model.

\section{Findings}

\section{Initial equilibrium and baseline path}

This section reports our baseline transition path findings. We start in Table 4 by comparing simulated with observed 2005 macro variables. The official GDP figures presented on the right side of Table 4 come from European Commission (2007, 2008), and, for India, OECD (2007e). The model's values for consumption, government purchases, and investment come very close to their official counterparts. Note especially that our model matches the very high rate of private consumption in the U.S. and very high rates of domestic investment in China and India. The model also does very well in matching relative GDP levels as reported by the World Bank (2007). The disaggregation of public goods is based, in part, on OECD $(2005,2006 \mathrm{~b})$ data on education outlays and, in part, on the aforementioned assumption that 80 percent of government health expenditures is government consumption. General public expenditures is calculated as a residual.

Our model's trade balances agree in sign, but not value, with actual values. But given that our model excludes regions outside of our five, one should probably not expect too much concurrence with respect to trade balances or current accounts. As already explained above, outlays of the social security systems were calibrated to yield the official values from OECD (2007b, c, d). The official contribution rates for pensions, health-care and disability were taken from SSA (2006) for the U.S. and from SSA (2007) for NEA (Japan), China and India. ${ }^{14}$ Obviously, our pension and health insurance contribution rates in China and India deviate from official figures. Our model assumes that all households in all regions are covered by the government's pension system whereas only about 23 percent of the total workforce in China and India are so covered. (Deutsche Bank Research, 2006).

Table 5 reports the baseline path of GDP for the five regions as well as the evolution of domestic capital stocks, labor demands, and average effective wage tax rates. All indexes for the five regions are expressed relative to year-2005 values in the U.S. The

\footnotetext{
${ }^{14}$ The official tax revenue data come from European Commission (2008) for U.S., EMU and NEA (Japan), from OECD (2002) for China, and from Poirson (2006) for India.
} 


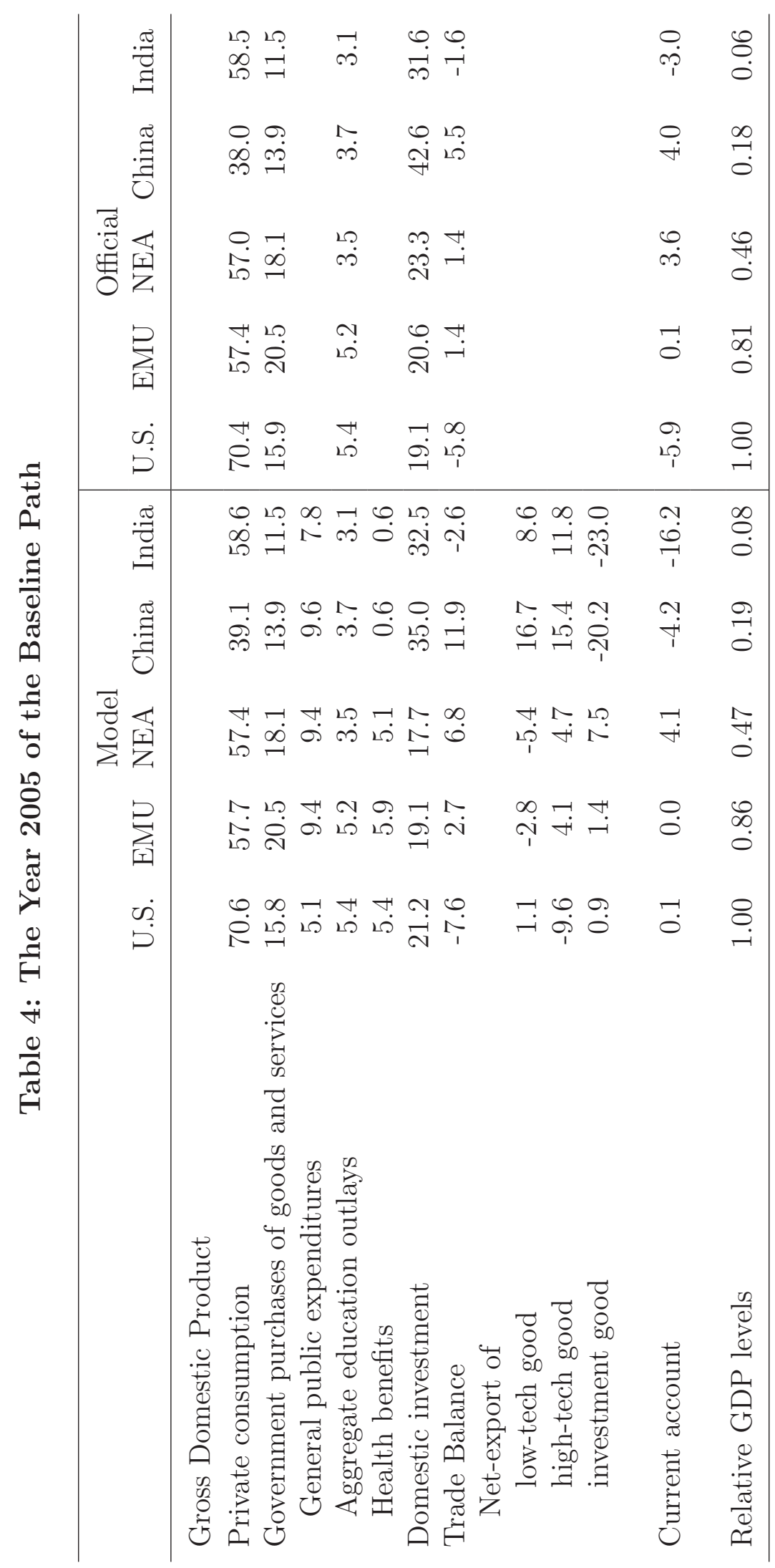




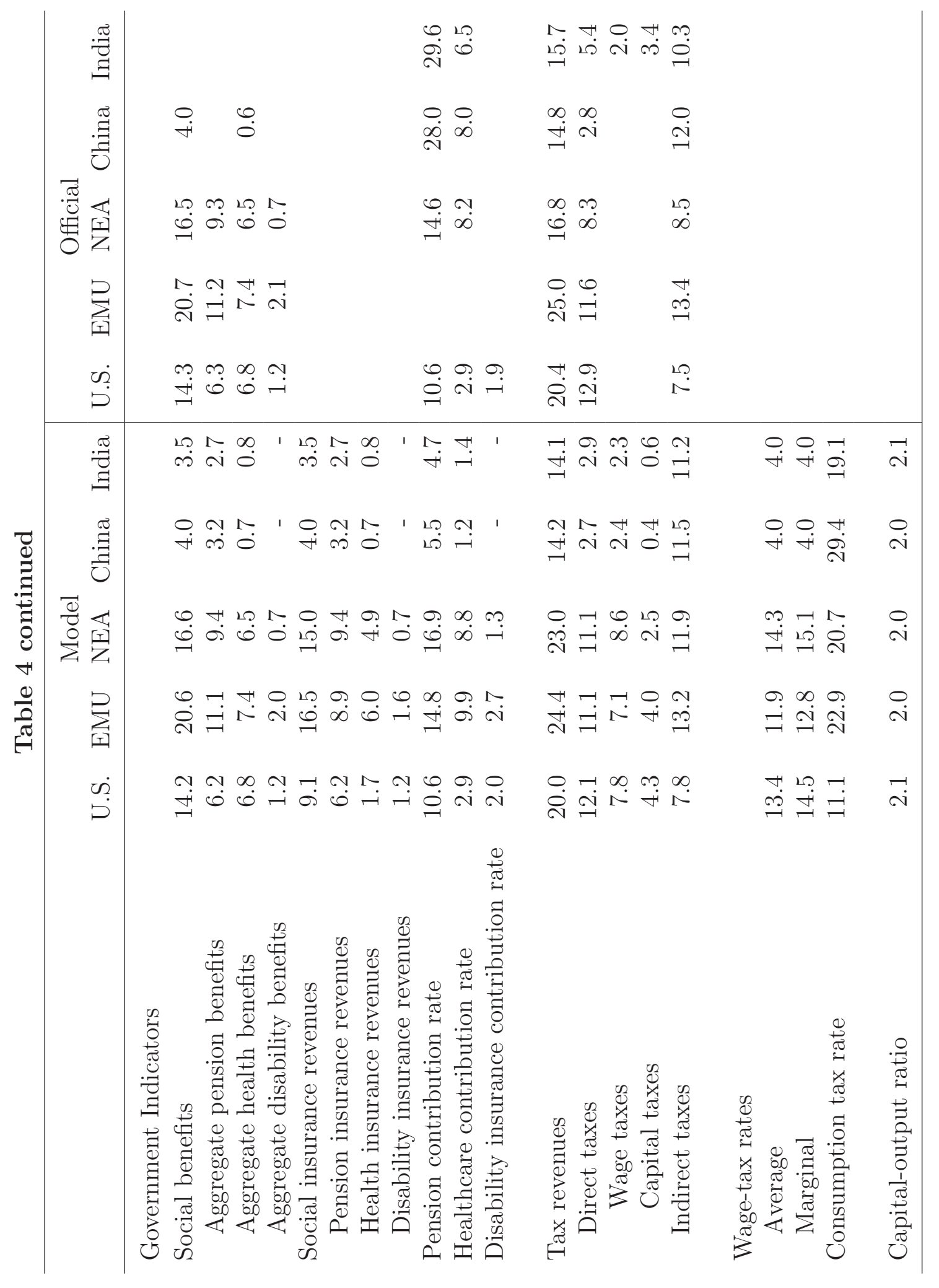


Table 5: Country-Specific Simulation Results of the Baseline Path

\begin{tabular}{lccccccccc}
\hline \multicolumn{1}{c}{} & \multicolumn{1}{c}{ Capital } & \multicolumn{2}{c}{ Labor Demand } & $\begin{array}{c}\text { Effective } \\
\text { Wage }\end{array}$ & $\begin{array}{c}\text { Pay- } \\
\text { roll }\end{array}$ & $\begin{array}{c}\text { Average } \\
\text { Wage }\end{array}$ & $\begin{array}{c}\text { Consump- } \\
\text { tion }\end{array}$ \\
Year & GDP & Stock & Low & Middle & High & Tax $^{a}$ & Tax $^{a}$ & Tax $^{a}$ & Tax $^{a, b}$ \\
\hline U.S. & & & & & & & & & \\
2005 & 1.00 & 1.00 & 1.00 & 1.00 & 1.00 & 38.9 & 15.5 & 13.4 & 11.1 \\
2010 & 1.11 & 1.11 & 1.10 & 1.10 & 1.11 & 40.6 & 16.5 & 13.8 & 11.5 \\
2030 & 1.63 & 1.71 & 1.60 & 1.56 & 1.65 & 55.0 & 24.6 & 17.2 & 15.2 \\
2050 & 2.76 & 3.08 & 2.79 & 2.54 & 2.65 & 62.1 & 22.6 & 19.6 & 24.8 \\
2100 & 4.61 & 4.55 & 5.11 & 4.56 & 4.67 & 68.7 & 28.4 & 20.3 & 25.0 \\
EMU & & & & & & & & & \\
2005 & 0.86 & 0.83 & 0.73 & 0.83 & 0.97 & 58.0 & 27.5 & 11.9 & 22.9 \\
2010 & 0.91 & 0.89 & 0.77 & 0.87 & 1.03 & 60.1 & 29.7 & 11.9 & 22.7 \\
2030 & 1.30 & 1.33 & 1.14 & 1.19 & 1.43 & 72.5 & 40.1 & 12.4 & 25.0 \\
2050 & 1.96 & 2.17 & 1.81 & 1.73 & 2.01 & 79.3 & 39.7 & 13.3 & 35.7 \\
2100 & 3.01 & 2.93 & 3.06 & 2.87 & 3.23 & 80.3 & 39.9 & 14.0 & 35.9 \\
NEA & & & & & & & & & \\
2005 & 0.47 & 0.46 & 0.39 & 0.46 & 0.53 & 58.4 & 27.0 & 14.3 & 20.7 \\
2010 & 0.48 & 0.47 & 0.40 & 0.46 & 0.54 & 62.0 & 31.5 & 14.3 & 19.4 \\
2030 & 0.73 & 0.74 & 0.69 & 0.71 & 0.77 & 67.6 & 35.6 & 14.3 & 21.5 \\
2050 & 1.02 & 1.13 & 1.04 & 0.95 & 0.99 & 72.0 & 36.2 & 15.0 & 26.3 \\
2100 & 1.31 & 1.30 & 1.51 & 1.30 & 1.30 & 69.6 & 35.5 & 16.1 & 22.0 \\
China & & & & & & & & & \\
2005 & 0.19 & 0.19 & 0.19 & 0.18 & 0.20 & 33.4 & 6.7 & 4.0 & 29.4 \\
2010 & 0.40 & 0.40 & 0.42 & 0.39 & 0.42 & 29.8 & 5.9 & 3.1 & 26.3 \\
2030 & 2.96 & 3.21 & 3.72 & 2.85 & 2.71 & 25.7 & 5.4 & 3.6 & 20.0 \\
2050 & 5.27 & 6.57 & 7.81 & 4.83 & 4.04 & 26.7 & 11.4 & 3.5 & 13.4 \\
2100 & 8.88 & 9.61 & 13.38 & 8.71 & 7.54 & 41.2 & 23.9 & 4.0 & 15.4 \\
India & & & & & & & & & \\
2005 & 0.08 & 0.08 & 0.08 & 0.07 & 0.08 & 26.1 & 6.1 & 4.0 & 19.1 \\
2010 & 0.13 & 0.14 & 0.13 & 0.13 & 0.14 & 20.4 & 5.4 & 2.5 & 14.3 \\
2030 & 1.29 & 1.39 & 1.40 & 1.21 & 1.25 & 22.9 & 4.6 & 3.1 & 18.0 \\
2050 & 4.12 & 4.86 & 4.71 & 3.76 & 3.67 & 28.5 & 8.5 & 3.3 & 20.0 \\
2100 & 11.04 & 11.92 & 16.32 & 10.82 & 9.43 & 39.8 & 20.6 & 4.2 & 17.7 \\
\hline
\end{tabular}

${ }^{a}$ In percent; ${ }^{b}$ These are nominal (tax exclusive) rates. The tax inclusive consumption tax rate (the nominal divided by 1 plus the nominal rate) is used in forming effective wage tax rates.

first point of interest is the growth of the U.S. economy relative to the EMU and NEA economies. U.S. GDP expands by a factor of 4.6 over the century, whereas EMU GDP expands by a factor of only 3.5, and NEA GDP expands by a factor of only 2.8. These differences reflects, in large part, demographic differences across the regions, particularly 
the absolute population decline in NEA.

China's GDP, in contrast, starts at 19 percent of the U.S. value, but overtakes the U.S. by 2020. But once China's productivity levels reach U.S. values, its growth slows. Consequently, by 2100, China's GDP is only 1.9 times the U.S. level. The results for India are also quite interesting. Thanks to India's slower productivity growth, its growth explosion occurs in the second half of the century. But by century's end, India's GDP is 2.4 times U.S. GDP and 1.2 times China's. Together, China and India account for 4.3 times U.S. GDP in 2100, and U.S. GDP, which accounts for 38.5 percent of total 5-region GDP in 2005, accounts for only 16.0 percent in 2100. In short, the U.S. becomes a small player in the developed world.

The growth of output can be explained, in part, by the growth of inputs. Table 5 shows that the capital stock in each region grows almost in lockstep with GDP in each region. Equilibrium labor demand (and supply) rise both because of technical progress (the expansion of effective time available to successive cohorts) and changes in labor supply. In the other regions, this growth also reflects changes in labor productivity as successive new cohorts of workers gradually attain U.S. productivity levels. The key points of interest in Table 5 are the very rapid expansions of labor supply in China between 2005 and 2030 and in India between 2050 and 2100.

Table 6 examines how components of GDP evolve in the five regions. Over the first 25 years, the U.S. runs sizeable annual trade deficits as it imports capital from China, whose very high saving rate leads to considerable asset accumulation and large trade surpluses. Ultimately, the returns from these investments in the U.S. must be repatriated, which explains why the U.S. runs such large trade surpluses toward the end of the century and why China runs such large trade deficits. We can see this clearly in the patterns of wealth accumulation and capital usage in the U.S. and China over time. In 2100 capital employed in the U.S. exceeds U.S. national wealth by a factor of two. In China, national wealth exceeds capital employed by one quarter. The EMU also ends up with a 2100 capital stock that is twice as large as its national wealth; i.e., if all it wealth were invested at home, citizens of the EMU would own only half of the region's total capital stock in 2100. In contrast to China, India uses much more capital than it owns until the very end of the century. In NEA there is a relatively close balance between employed capital and owned capital over the period. The table shows that trade and current account deficits can be very sizeable for decades before they reverse their sign and that their pattern is not easily forecast. I.e., there are a host of complex, interconnected factors determining their time paths including inter-regional differences in saving behavior, demographics, and fiscal policies.

Consider next how average effective wage tax rates evolve. As indicated in Table 5, this 
Table 6: GDP and Its Components in the Baseline Path

\begin{tabular}{|c|c|c|c|c|c|c|c|}
\hline & Year & $\begin{array}{c}\text { Consump- } \\
\text { tion } \\
/ \mathrm{GDP}^{a}\end{array}$ & $\begin{array}{l}\text { Invest- } \\
\text { ment } \\
/ \mathrm{GDP}^{a}\end{array}$ & $\begin{array}{c}\text { Gov. Pur- } \\
\text { chases } \\
\text { /GDP }^{a}\end{array}$ & $\begin{array}{r}\text { Trade } \\
\text { Balance } \\
/ \mathrm{GDP}^{a}\end{array}$ & $\begin{array}{l}\text { Current } \\
\text { Account } \\
/ \mathrm{GDP}^{a}\end{array}$ & $\begin{array}{l}\text { National } \\
\text { Wealth }^{b}\end{array}$ \\
\hline \multirow[t]{5}{*}{ U.S. } & 2005 & 70.6 & 21.2 & 15.8 & -7.6 & 0.1 & 1.30 \\
\hline & 2010 & 70.3 & 17.6 & 16.1 & -4.0 & 4.1 & 1.46 \\
\hline & 2030 & 66.3 & 22.7 & 20.4 & -9.4 & -7.8 & 1.81 \\
\hline & 2050 & 45.5 & 22.1 & 21.4 & 11.1 & -2.5 & 1.09 \\
\hline & 2100 & 46.7 & 17.3 & 21.4 & 14.5 & 2.7 & 2.25 \\
\hline \multirow[t]{5}{*}{ EMU } & 2005 & 57.7 & 19.1 & 20.5 & 2.7 & 0.0 & 0.74 \\
\hline & 2010 & 58.5 & 16.4 & 20.9 & 4.1 & 2.5 & 0.83 \\
\hline & 2030 & 54.2 & 21.4 & 24.4 & 0.0 & -4.7 & 1.06 \\
\hline & 2050 & 40.7 & 20.4 & 26.2 & 12.6 & -1.1 & 0.72 \\
\hline & 2100 & 42.2 & 17.1 & 26.1 & 14.5 & 3.0 & 1.46 \\
\hline \multirow[t]{5}{*}{ NEA } & 2005 & 57.4 & 17.7 & 18.1 & 6.8 & 4.1 & 0.40 \\
\hline & 2010 & 61.2 & 15.5 & 18.9 & 4.4 & 5.0 & 0.48 \\
\hline & 2030 & 53.8 & 21.0 & 22.7 & 2.4 & -0.6 & 0.65 \\
\hline & 2050 & 46.0 & 20.2 & 24.9 & 8.8 & 1.6 & 0.72 \\
\hline & 2100 & 57.1 & 17.1 & 24.5 & 1.4 & 5.7 & 1.54 \\
\hline \multirow[t]{5}{*}{ China } & 2005 & 39.1 & 35.0 & 13.9 & 11.9 & -4.2 & 0.06 \\
\hline & 2010 & 34.0 & 53.6 & 13.5 & -1.0 & -14.5 & 0.18 \\
\hline & 2030 & 52.5 & 29.1 & 14.2 & 4.0 & 13.7 & 4.47 \\
\hline & 2050 & 76.2 & 26.2 & 16.3 & -18.7 & 6.7 & 13.71 \\
\hline & 2100 & 75.5 & 18.8 & 16.6 & -10.8 & -2.8 & 12.66 \\
\hline \multirow[t]{5}{*}{ India } & 2005 & 58.6 & 32.5 & 11.5 & -2.6 & -16.2 & 0.04 \\
\hline & 2010 & 50.0 & 46.2 & 11.4 & -7.6 & -25.1 & 0.04 \\
\hline & 2030 & 51.4 & 35.9 & 11.5 & 1.2 & -16.5 & 0.38 \\
\hline & 2050 & 50.1 & 28.7 & 12.9 & 8.3 & -6.8 & 1.54 \\
\hline & 2100 & 68.4 & 19.7 & 13.4 & -1.5 & -0.4 & 12.40 \\
\hline
\end{tabular}

${ }^{a}$ In percent; ${ }^{b}$ National wealth is defined as private assets minus government debt.

tax rate comprises the payroll tax rate, the average wage (labor income) tax rate, and the average consumption tax rate. ${ }^{15}$ All five regions experience dramatic increases over time in tax rates. In the U.S., average effective wage tax rates rise from 38.9 percent in 2005 to 68.7 percent in 2100 . This is a larger percentage increase than in the EMU, which starts with a 58.0 percent average rate and ends up in 2100 with an 80.3 percent average rate! In NEA, the average effective wage tax rate rises from 58.4 percent to 69.6 percent.

\footnotetext{
${ }^{15}$ Consumption tax rates are expressed here on a tax inclusive basis to make it comparable to payroll and wage tax rates.
} 
These are startlingly high tax rates in the case of the three developed regions. Do they make sense? They do given two factors. First, all three regions have very significant pay-go social insurance programs whose benefits are disproportionately distributed to the elderly. Given the dramatic aging (see table 1) now underway, one would expect major tax hikes simply to finance these benefits. Second, healthcare benefit levels have risen and can be expected to continue to rise much faster than per capita GDP in each of the three regions. Recall that we are assuming for the U.S., EMU, and NEA a growth rate in healthcare benefit levels that is two percentage points higher than the growth rate of per capita GDP for the first 20 years of the transition and one percentage point higher for the following 10 years. As indicated in Hagist and Kotlikoff (2009), this is actually a rather conservative assumption. In the U.S., for example, the 1970-2002 average annual growth rate of real government healthcare benefit exceeded the average annual growth rate of per capita GDP by 2.6 percentage points. Since 2002, the differential appears to have been much larger thanks to the introduction of Medicare Part D prescription drug benefits and a huge expansion of Medicaid coverage.

Tax rates in both China and India also end up much higher at the end of the century, but before then they fall considerably, in the case of China, and moderately, in the case of India. The explanation is the expansion of the labor income of younger generations thanks to our assumptions concerning cohort-specific labor-productivity increases. Over time, as the entire labor force becomes fully productive and as these fully productive generations retire, their higher earnings histories translate into higher old age healthcare and pension benefits, whose financing requires higher tax rates. As indicated, we're also assuming a very sizable growth rate in healthcare benefit levels (4 percentage points above the growth rate of per capita GDP) for the next four decades in these two regions. Our rationale is that these countries are starting out with very low levels of healthcare benefits; and their governments will face strong pressure from their populations to improve this situation.

Table 5 shows the compositions of the tax rate increases. In the U.S. and EMU they are coming disproportionately from increases in payroll and consumption tax rates. In NEA, the major increase is from payroll taxes. This is also the case in China and India, where long-run average wage tax rates (the rates applied to wages via income taxation) differ either not at all or very little from their initial values and where long-run consumption tax rates are lower and, in the case of China, significantly lower, than their initial values. The decline in consumption tax rates compared to wage tax rates reflects the expansion of the consumption tax base relative to the wage tax base. The explanation lies in a) changes over time in China's and India's time-preference rates that lead the countries to spend more and save less and b) the significant aging of the two countries' populations, which generates relatively large numbers of elderly whose principal occupation is consuming, rather than working. 
Table 7: Factor Prices in the Baseline Path

\begin{tabular}{ccccc}
\hline & \multirow{2}{*}{$\begin{array}{c}\text { Interest } \\
\text { Year }\end{array}$} & Rate & \multicolumn{3}{c}{ Wage Rates* } \\
\cline { 3 - 5 } & 12.7 & 1.00 & 2.99 & 5.83 \\
2005 & 12.4 & 0.98 & 3.03 & 5.87 \\
2010 & 10.9 & 0.84 & 3.13 & 6.37 \\
2030 & 9.1 & 0.75 & 3.24 & 7.16 \\
2050 & 11.5 & 0.68 & 2.97 & 6.86 \\
2100 & & & & \\
\hline
\end{tabular}

* At age 21 per unit of effective time

Changes in factor prices are shown in Table 7. As in Fehr, et. al. (2007), the interest rate decreases through mid-century thanks in large part to China's extremely high propensity to save. In the second half of the century it increases again, but ends up in 2100 some 120 basis points below the year-2005 value. These real interest rate developments are interesting; even more interesting is what happens to the levels and distribution of real wage rates.

According to Table 7, low-skilled wages per unit of effective time decrease continuously during the century. By mid-century the level of wages for low-skilled workers is only 75 percent of the year-2005 level; in 2100 it is only 68 percent of the initial level. Wages per unit of effective time for medium-skilled workers remain almost unchanged during the transition. In contrast, the wage rate of high-skilled workers per unit of effective time increases through mid-century; in 2050, it is 23 percent above its initial value. After 2050, the high-skilled wage rate falls, stabilizing in 2075 at 18 percent above the 2005 level. Wage-skill differentials in the medium and long runs are much larger than those that now exist. In 2005 the high-skilled wage rate exceeds the low-skilled rate by a factor of 5.83. By 2050 this factor is 9.5. In 2100 the factor is 10.1 !

Producer prices remain almost constant during the transition; i.e., we see major changes in relative factor rewards with only minor changes in relative producer prices. Producer prices can be traced to unit costs, but when relative factor prices change, unit costs need change very little as the costs of some factors rise and other fall. In addition, substitution away from relatively expensive factors limits changes in producer prices.

Our model generates significant changes in the region-specific structure of production during the transition. In all regions investment good production increases during the first half of the century and decreases afterwards. Production of the low-tech good is completely eliminated in the developed regions in the medium and long run. Interestingly, the high-tech good sector (good 4) is reduced in China in the short run, but increases 
again in the long run. In contrast, public good production increases in all regions during the transition. Finally, the service sector (good 1) declines somewhat in the developed regions and expands in the developing regions. Our model also generates an increasing demand for services over time, whereas the demand for the traded low-tech and high-tech good decreases slightly in all regions. These developments reflect the changing demands of aging populations due to the specific age-dependent consumption shares assumed for the different consumption goods.

Over time, the developed regions as well as India after 2030 become major importers of the low-tech consumption good (good 3) while China becomes the world's primary exporter of this good. The opposite holds for the high-tech good which is mainly imported by China and exported by the U.S. (second half of the century), EMU and India. China and India are the main importers of the investment good while this good is exported by the developed regions. Finally, all three developed regions become increasingly dependent over time on off-shore low-skilled labor. By the end of the century between one fifth and one quarter of the developed regions' low-skilled labor forces are hired off shore.

\section{Alternative Policies}

We explore next how shutting down trade with China and India would affect the developed regions. We consider this case by simply excluding India and China from our simulation model. The calibration of the remaining regions remains unchanged. Table 8 reports macroeconomic variables. Note that we express all indexes relative to the U.S. year-2005 levels of the baseline path.

As the table indicates, excluding China and India has dramatic effects on the economic development in the developed regions. Capital stocks in all three regions in the initial years of the transition are higher compared to the five-region case since more capital now remains in the developed world. For example, in 2020 the capital stock index in the U.S. is 1.46 compared to 1.27 in the five-region simulation (see Table 5). However, in all three regions, capital stocks as well as levels of GDP grow to a much smaller extent over time compared with the baseline. These developments are also reflected in the path for payroll tax rates. These rates increase to a larger extent in the medium run. In the short and long run they are below their respective baseline values.

The most interesting finding of excluding China and India is its impact on the wage structure, see Table 9. As before, wage rates for low-skilled workers decrease during the transition but to a much smaller extent than in the baseline. By the end of the century, the low-skilled wage rate is 95 percent of the year-2005 level; it was 68 percent of the year-2005 level in the base case. The reason, of course, is that absent China and India there is no major increase over time in the relative world supply of low-skilled workers. Wages for middle-skilled workers are largely unchanged, but the high-skilled wage rate 


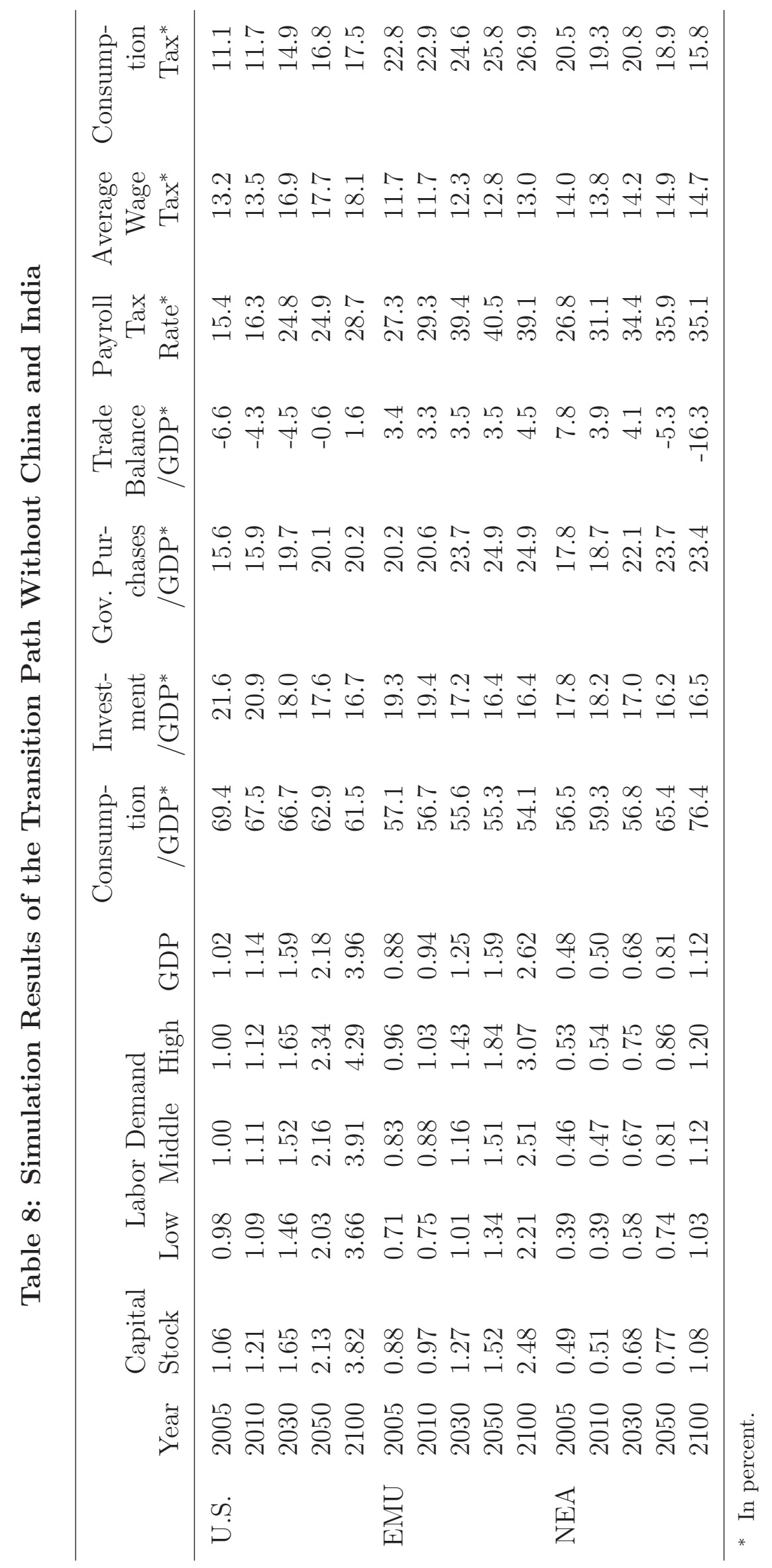


Table 9: Factor Prices in Alternative Policy Paths

\begin{tabular}{lccccc}
\hline & & Interest & \multicolumn{3}{c}{ Wage Rates* } \\
\cline { 4 - 6 } Policy & Year & Rate & Low & Middle & High \\
\hline Eliminating & 2005 & 11.9 & 1.05 & 3.04 & 5.96 \\
Trade with & 2010 & 11.5 & 1.06 & 3.08 & 6.02 \\
China and & 2030 & 11.7 & 1.04 & 3.08 & 5.95 \\
India & 2050 & 12.7 & 0.99 & 2.98 & 5.87 \\
& 2100 & 12.8 & 1.00 & 2.98 & 5.81 \\
Different & 2005 & 12.6 & 1.00 & 2.99 & 5.84 \\
Growth of & 2010 & 12.1 & 1.01 & 3.05 & 5.91 \\
Labor & 2030 & 12.3 & 0.90 & 3.03 & 5.98 \\
Productivity & 2050 & 11.8 & 0.77 & 3.01 & 6.43 \\
in China & 2100 & 11.2 & 0.68 & 2.99 & 6.93 \\
Limited & 2005 & 12.6 & 1.00 & 2.99 & 5.85 \\
Growth of & 2010 & 12.5 & 0.98 & 3.02 & 5.85 \\
Healthcare & 2030 & 11.0 & 0.85 & 3.14 & 6.33 \\
Benefits & 2050 & 8.9 & 0.77 & 3.27 & 7.18 \\
& 2100 & 10.8 & 0.70 & 3.04 & 6.97 \\
Adjusting & 2005 & 12.7 & 1.00 & 2.99 & 5.82 \\
Income & 2010 & 12.4 & 0.99 & 3.03 & 5.84 \\
Class & 2030 & 11.0 & 0.96 & 3.16 & 6.12 \\
Shares & 2050 & 9.2 & 1.00 & 3.31 & 6.61 \\
& 2100 & 11.5 & 1.05 & 3.09 & 6.02 \\
\hline$*$
\end{tabular}

* At age 21 per unit of effective time.

ends up 2.5 percent below its 2005 level compared to 18 percent above its 2005 level when China and India are included.

Developed world long-run GDPs are also significantly affected by moving to autarky with respect to China and India. For example, U.S. GDP in 2100 is reduced by 14 percent. Total developed region GDP is reduced by 17 percent. These reductions in GDP suggest that there are sizeable gains from trade, which could be shared with low-skilled workers were the developed countries to adopt the right redistribution policies. Exploring such policies is on our agenda for the next draft of this paper.

To assess the sensitivity of our results to our labor productivity assumptions, we ran two further simulations. The first assumes that the labor productivity of successive new cohorts of workers in China increases to the developed world's level in 25 years instead of 15 years. The second run assumes an adjustment over 50 years. Since the qualitative results of these two simulation runs were very similar, with much slower economic growth 
in China in the short and medium runs than in the baseline path. For example, China's 2030 GDP is now only 47 percent of its baseline level. Slower growth in China means a smaller supply of Chinese saving to the rest of the world. This, in turn, means lower rates of domestic investment and slower rates of growth in the other four regions. This translates into higher payroll and other tax rates and less growth in real wage rates, particularly among high-skilled workers (see Table 9).

Our next exercise shows how preventing government healthcare benefits from growing over the next decades at higher rates than per capita GDP would affect the global equilibrium and, most importantly, region-specific tax rates. The key differences here are with respect to long-run tax rates. As shown in Table 10, the U.S. long-run average effective wage tax rate is now 58.4 percent, rather than 68.7 percent. In the EMU, it's 69.5 percent, not 80.3 percent. The NEA rate ends ups at 59.2 percent, compared to 69.6 percent. China's rate in 2100 is 34.3 percent, not 41.2 percent. And India's rate is 32.7 percent, rather than 39.8 percent. Interestingly, the lower tax rates don't manifest themselves in higher GDPs. The reason is income effects on labor supply; agents in our model respond to their tax cuts by consuming more leisure, not working harder, which leaves aggregate output little changed from the baseline case.

Finally, we simulated successful education policy in China and India by which we mean that over the next 30 years the two countries succeed in providing new cohorts with the same distribution of skills as is the case for new cohorts in the developed economies. ${ }^{16}$ Recall that in 2005, we assume that 22 percent of the overall population in China and India belong to the low-skill group, 25 percent to the highest, and 53 percent to the middle. By 2035, these shares have converged to 15, 55, and 30 percent, respectively.

Simulating this policy generates little difference in overall macroeconomic conditions (see Table 11). The main effect is on relative GDPs. Year-2100 GDPs in the developed regions are about 8 percent smaller, while they are about 10 percent larger in China and India. The real impact of the policy is on wages. As shown in Table 9, the wage rates per efficiency unit of all three skill classes now ultimately increase and wage inequality remains roughly constant over time. Rather than falling to .68 in 2100, the low-skilled wage is now 1.05 at Century's end. This improvement in low-skilled wage rates comes at the price of a wage-rate reduction for high-skilled workers. In 2100 their wage rate is now 6.02 compared with 6.86 in the base case. As for inequality, the base-case ratio of high-skilled to low-skilled wage rates in 2100 was 10.1. It's now 5.7. The middle-skilled workers also experience some improvement in their relative remuneration. Their long-run wage rate is now 3.09 compared with 2.97 in the base case.

\footnotetext{
${ }^{16}$ Note that we still assume that members of each income class inherit from their parents' skill class.
} 
Table 10: Limiting Growth in Healthcare Benefits

\begin{tabular}{|c|c|c|c|c|c|c|c|c|c|}
\hline Year & GDP & $\begin{array}{r}\text { Capital } \\
\text { Stock }\end{array}$ & $\begin{array}{r}\text { La } \\
\text { Low }\end{array}$ & $\begin{array}{l}\text { or Dema } \\
\text { Middle }\end{array}$ & $\begin{array}{l}\text { nd } \\
\text { High }\end{array}$ & $\begin{array}{c}\text { Effective } \\
\text { Wage } \\
\operatorname{Tax}^{a}\end{array}$ & $\begin{array}{c}\text { Pay- } \\
\text { roll } \\
\operatorname{Tax}^{a}\end{array}$ & $\begin{array}{r}\text { Average } \\
\text { Wage } \\
\text { Tax }^{a}\end{array}$ & $\begin{array}{c}\text { Consump- } \\
\text { tion } \\
\operatorname{Tax}^{a, b}\end{array}$ \\
\hline \multicolumn{10}{|l|}{ U.S. } \\
\hline 2005 & 1.00 & 1.00 & 1.00 & 0.99 & 0.99 & 39.1 & 15.6 & 13.5 & 11.1 \\
\hline 2010 & 1.09 & 1.11 & 1.10 & 1.09 & 1.10 & 39.7 & 16.3 & 13.4 & 11.1 \\
\hline 2030 & 1.63 & 1.74 & 1.61 & 1.55 & 1.63 & 48.1 & 22.8 & 14.4 & 12.2 \\
\hline 2050 & 2.74 & 3.18 & 2.74 & 2.48 & 2.55 & 52.5 & 20.5 & 16.2 & 18.8 \\
\hline 2100 & 4.59 & 4.82 & 5.03 & 4.41 & 4.44 & 58.4 & 26.3 & 16.6 & 18.4 \\
\hline \multicolumn{10}{|l|}{ EMU } \\
\hline 2005 & 0.86 & 0.83 & 0.73 & 0.82 & 0.96 & 58.1 & 27.6 & 11.9 & 22.9 \\
\hline 2010 & 0.91 & 0.88 & 0.77 & 0.86 & 1.01 & 59.0 & 28.9 & 11.9 & 22.3 \\
\hline 2030 & 1.28 & 1.33 & 1.16 & 1.19 & 1.38 & 64.5 & 33.9 & 12.0 & 22.9 \\
\hline 2050 & 1.91 & 2.19 & 1.80 & 1.69 & 1.88 & 68.5 & 32.3 & 12.7 & 30.8 \\
\hline 2100 & 2.94 & 3.03 & 3.04 & 2.77 & 2.99 & 69.5 & 33.0 & 13.3 & 30.2 \\
\hline \multicolumn{10}{|l|}{ NEA } \\
\hline 2005 & 0.47 & 0.46 & 0.39 & 0.46 & 0.53 & 58.6 & 27.1 & 14.4 & 20.7 \\
\hline 2010 & 0.48 & 0.47 & 0.40 & 0.46 & 0.54 & 60.9 & 30.6 & 14.3 & 19.1 \\
\hline 2030 & 0.73 & 0.74 & 0.69 & 0.70 & 0.74 & 59.4 & 29.5 & 13.7 & 19.4 \\
\hline 2050 & 1.01 & 1.15 & 1.02 & 0.92 & 0.93 & 60.9 & 28.5 & 14.1 & 22.4 \\
\hline 2100 & 1.29 & 1.36 & 1.47 & 1.25 & 1.22 & 59.2 & 28.6 & 15.0 & 18.5 \\
\hline \multicolumn{10}{|c|}{ China } \\
\hline 2005 & 0.19 & 0.19 & 0.19 & 0.18 & 0.21 & 33.7 & 6.7 & 4.0 & 29.8 \\
\hline 2010 & 0.40 & 0.40 & 0.42 & 0.39 & 0.43 & 29.6 & 5.6 & 3.1 & 26.4 \\
\hline 2030 & 2.94 & 3.20 & 3.68 & 2.82 & 2.68 & 22.7 & 2.8 & 3.6 & 19.5 \\
\hline 2050 & 5.27 & 6.76 & 7.78 & 4.80 & 3.89 & 19.6 & 4.6 & 3.5 & 13.0 \\
\hline 2100 & 8.89 & 10.11 & 13.24 & 8.55 & 7.21 & 34.3 & 17.3 & 4.0 & 14.9 \\
\hline \multicolumn{10}{|l|}{ India } \\
\hline 2005 & 0.08 & 0.08 & 0.08 & 0.07 & 0.08 & 26.3 & 6.1 & 4.0 & 19.3 \\
\hline 2010 & 0.13 & 0.14 & 0.13 & 0.13 & 0.14 & 20.2 & 5.1 & 2.5 & 14.4 \\
\hline 2030 & 1.27 & 1.38 & 1.39 & 1.20 & 1.23 & 20.4 & 2.3 & 3.1 & 17.6 \\
\hline 2050 & 4.13 & 5.01 & 4.70 & 3.73 & 3.57 & 22.2 & 2.9 & 3.3 & 19.1 \\
\hline 2100 & 11.08 & 12.58 & 16.17 & 10.65 & 9.08 & 32.7 & 14.2 & 4.1 & 16.8 \\
\hline
\end{tabular}

${ }^{a}$ In percent; ${ }^{b}$ These are nominal (tax exclusive) rates. The effective (tax inclusive) tax rate (the nominal divided by 1 plus the nominal rate) is used in forming effective wage tax rates.

\section{Conclusions}

This paper developed a new 5-region, dynamic, general equilibrium, life-cycle model to analyze the impact of globalization on the world's demographic/fiscal transition path, particularly the course of wage inequality. Our model includes multiple traded and non- 
Table 11: Successful Chinese and Indian Education Policy

\begin{tabular}{|c|c|c|c|c|c|c|c|c|c|}
\hline Year & GDP & $\begin{array}{r}\text { Capital } \\
\text { Stock }\end{array}$ & $\begin{array}{l}\text { La } \\
\text { Low }\end{array}$ & $\begin{array}{l}\text { or Dema } \\
\text { Middle }\end{array}$ & High & $\begin{array}{c}\text { Effective } \\
\text { Wage } \\
\text { Tax }^{a}\end{array}$ & $\begin{array}{l}\text { Pay- } \\
\text { roll } \\
\operatorname{Tax}^{a}\end{array}$ & $\begin{array}{r}\text { Average } \\
\text { Wage } \\
\text { Tax }^{a}\end{array}$ & $\begin{array}{c}\text { Consump- } \\
\text { tion } \\
\operatorname{Tax}^{a, b}\end{array}$ \\
\hline \multicolumn{10}{|l|}{ U.S. } \\
\hline 2005 & 1.00 & 1.00 & 0.99 & 1.00 & 1.00 & 38.9 & 15.5 & 13.4 & 11.1 \\
\hline 2010 & 1.11 & 1.11 & 1.09 & 1.10 & 1.11 & 40.6 & 16.5 & 13.8 & 11.5 \\
\hline 2030 & 1.58 & 1.67 & 1.45 & 1.50 & 1.61 & 53.9 & 24.5 & 16.7 & 14.5 \\
\hline 2050 & 2.55 & 2.88 & 2.13 & 2.32 & 2.55 & 58.4 & 22.2 & 18.1 & 22.1 \\
\hline 2100 & 4.31 & 4.38 & 3.74 & 4.11 & 4.64 & 65.6 & 28.5 & 18.9 & 22.3 \\
\hline \multicolumn{10}{|l|}{ EMU } \\
\hline 2005 & 0.86 & 0.83 & 0.73 & 0.83 & 0.97 & 57.9 & 27.5 & 11.8 & 22.9 \\
\hline 2010 & 0.91 & 0.89 & 0.77 & 0.87 & 1.02 & 60.2 & 29.8 & 11.9 & 22.7 \\
\hline 2030 & 1.25 & 1.29 & 1.00 & 1.14 & 1.40 & 70.6 & 39.3 & 12.0 & 23.9 \\
\hline 2050 & 1.83 & 2.04 & 1.40 & 1.60 & 1.96 & 75.1 & 38.0 & 12.6 & 32.5 \\
\hline 2100 & 2.80 & 2.80 & 2.24 & 2.60 & 3.21 & 76.5 & 38.6 & 13.3 & 32.6 \\
\hline \multicolumn{10}{|l|}{ NEA } \\
\hline 2005 & 0.47 & 0.46 & 0.39 & 0.46 & 0.53 & 58.4 & 27.0 & 14.3 & 20.7 \\
\hline 2010 & 0.48 & 0.47 & 0.40 & 0.46 & 0.54 & 62.1 & 31.5 & 14.4 & 19.4 \\
\hline 2030 & 0.69 & 0.70 & 0.59 & 0.67 & 0.75 & 65.1 & 34.4 & 13.8 & 20.3 \\
\hline 2050 & 0.94 & 1.05 & 0.79 & 0.87 & 0.95 & 67.0 & 34.0 & 14.0 & 23.3 \\
\hline 2100 & 1.20 & 1.23 & 1.03 & 1.15 & 1.29 & 64.8 & 33.8 & 14.8 & 19.3 \\
\hline \multicolumn{10}{|c|}{ China } \\
\hline 2005 & 0.19 & 0.19 & 0.19 & 0.18 & 0.20 & 33.4 & 6.7 & 4.0 & 29.3 \\
\hline 2010 & 0.40 & 0.40 & 0.42 & 0.39 & 0.43 & 29.8 & 5.9 & 3.1 & 26.2 \\
\hline 2030 & 3.14 & 3.36 & 3.34 & 3.00 & 3.05 & 26.0 & 5.3 & 3.6 & 20.6 \\
\hline 2050 & 5.79 & 7.16 & 6.19 & 5.17 & 4.96 & 27.4 & 11.4 & 3.6 & 14.1 \\
\hline 2100 & 9.77 & 10.47 & 8.87 & 9.19 & 9.77 & 41.5 & 23.9 & 4.1 & 15.6 \\
\hline \multicolumn{10}{|l|}{ India } \\
\hline 2005 & 0.08 & 0.08 & 0.08 & 0.07 & 0.08 & 26.1 & 6.1 & 4.0 & 19.1 \\
\hline 2010 & 0.13 & 0.14 & 0.13 & 0.13 & 0.14 & 20.2 & 5.3 & 2.5 & 14.1 \\
\hline 2030 & 1.37 & 1.46 & 1.23 & 1.28 & 1.41 & 23.1 & 4.5 & 3.1 & 18.3 \\
\hline 2050 & 4.56 & 5.31 & 3.71 & 4.08 & 4.49 & 29.2 & 8.5 & 3.4 & 20.9 \\
\hline 2100 & 12.23 & 13.07 & 10.94 & 11.53 & 12.29 & 40.2 & 20.6 & 4.2 & 18.2 \\
\hline
\end{tabular}

${ }^{a}$ In percent; ${ }^{b}$ These are nominal (tax exclusive) rates. The effective (tax inclusive) tax rate (the nominal divided by 1 plus the nominal rate) is used in forming effective wage tax rates.

traded goods whose production functions differentially utilize high-skilled, middle-skilled, and low-skilled labor as well as capital. Thanks to the projected catch-up of labor productivity in China and India and the fact that these regions are relatively highly endowed 
with low-skilled workers, there is an ongoing and very major increase in the world's relative endowment of low-skilled labor. This spells portends further dramatic increases in wage rate inequality over the century.

Our model also shows that the dramatic aging process now underway in the developed world, China and, ultimately, India, coupled with very high projected growth rates in government-financed healthcare benefits, will greatly challenge fiscal institutions leading to tremendous increases in effective wage-tax rates - increases that are barely feasible in our model and may be infeasible in the real world. Notwithstanding these tax hikes, the model predicts world-wide capital deepening thanks to large supplies of capital forthcoming from China and India, whose saving rates are assumed to remain relatively high over the medium term.

Excluding China and India from trade with the developed regions succeeds in limiting wage-rate inequality. But it comes at a major cost to developed world output, reducing the long-run (year 2100) GDP of the U.S., EMU, and Japan (plus Taiwan and Korea) by 17 percent compared with the case of free trade. It also reduces capital intensivity, raising the long-run real interest rate by 90 basis point. On the other hand, this policy keeps the wage rates of low-skilled workers from falling over time, leaves the long-run wage rate of middle-skilled workers essentially unchanged, and leaves the long-run wage rates of high skilled workers 2.5 percent lower rather than 23 percent higher. ${ }^{17}$

In suggesting that trade with China and India may increasingly undermine the relative prospects of low-skilled and middle-skilled workers, we don't contend that this troubling aspect of globalization has been the dominant force in recent decades in exacerbating income inequality. But the main future concern is surely the effective arrival of hundreds of millions of low-skilled Chinese and Indian workers able to compete on equal terms with low-skilled workers in the developed world.

Worsening wage rate inequality is not inevitable, however. As we show, if Chinese and Indian education policies begin to produce new high-, middle-, and low-skilled workers in the same proportions as now occurs in the developed regions, the exacerbation of wage inequality can be fully reversed. Consequently, one of the best ways the developed world can assist its unskilled workers is to help improve education in China and India.

\footnotetext{
${ }^{17}$ These wage rates are measured per efficiency unit and abstract from the model's assumed increase in the labor efficiency of successive cohorts no matter their skill levels. This efficiency increase, recall, comes in the form of expansion in effective time endowments.
} 


\section{References}

Altig, D., A.J. Auerbach, L.J. Kotlikoff, K.A. Smetters and J. Walliser (2001): Simulating Fundamental Tax Reform in the United States, American Economic Review 91, 574-595.

Auerbach, A.J. and L.J. Kotlikoff (1987): Dynamic Fiscal Policy, Cambridge.

Autor, D.H., L.F. Katz and M.S. Kearney (2008): Trends in U.S. Wage Inequality: ReAssessing the Revisionists, Review of Economics and Statistics 90(2), 300-323.

Autor, D.H., L.F. Katz and M.S. Kearney (2006): The Polarization of the U.S. Labor Market, American Economic Review 96(2), 189-194.

Bosworth, B. and S.M. Collins (2008): Accounting for Growth: Comparing China and India, Journal of Economic Perspectives 22, 45-66.

Bound, J. and G. Johnson (1992): Changes in the Structure of Wages in the 1980's: An Evaluation of Alternative Explanations, American Economic Review 82(3), 371-392.

Card, D. and J. E. DiNardo (2002): Skill-Biased Technological Change and Rising Wage Inequality: Some Problems and Puzzles, Journal of Labor Economics 20, 733-783.

Council for Economic Planning and Development (CEPD) (2007): Population Projections for Taiwan Area 2006-2051. http://www.cepd.gov.tw/

Deutsche Bank Research (2006): China's pension system, Current Issues, China Special, February 17, 2006, Frankfurt.

Feenstra, R.C. and G.H. Hanson (1996): Globalization, Outsourcing and Wage Inequality, American Economic Review 86(2), 240-245.

Feenstra, R.C. and G.H. Hanson (1999): The Impact of Outsourcing and High-Technology Capital on Wages: Estimates for the United States, 1979-1990, Quarterly Journal of Economics 114, 907-940.

Fehr, H., S. Jokisch, and L.J. Kotlikoff (2007): Will China Eat our Lunch or Take us to Dinner? Simulating the Transition Paths of the United States, the European Union, Japan, and China, in: T. Ito and A.K. Rose (Eds.), Fiscal Policy and Management in East Asia, University of Chicago Press, 133-193.

Eckstein, Z. and E. Nagypal (2004): The Evolution of U.S. Earnings Inequality 19612002, Federal Reserve Bank of Minneapolis Quarterly Review 28, 10-29. 
European Commission (2008): Statistical Annex of European Economy, Spring 2008, Brussels.

European Commission (2007): Economic Forecast Spring 2007, European Economy 2, Brussels.

Gordon, R.J. and I. Dew-Becker (2007): Selected Issues in the Rise of Income Inequality, Brookings Papers on Economic Activity 38(2), 169-192.

Hagist, C. and L.J. Kotlikoff (2009): Who's Going Broke? Comparing Healthcare Costs in ten OECD Countries, Hacienda Pública Española (forthcoming).

Hornstein, A., P. Krusell and G.L Violante (2005): The Effects of Technical Change on Labor Market Inequalities, in: P. Aghion and S.N. Durlauf (eds.), Handbook of Economic Growth 1B, Amsterdam: Elsevier, 1275-1370.

International Monetary Fund (IMF) (2005): Staff Report on India, December 22, 2005.

James, E. (2002): How can China Solve its Old-age Security Problem? The Interaction between Pension, State and Financial Market Reform, Journal of Pension Economics and Finance 1(1), 53-75.

Kotlikoff, L.J., K.A. Smetters and J. Walliser (2007): Mitigating America's demographic dilemma by pre-funding social security, Journal of Monetary Economics 54, 247-266.

Lawrence, R.Z. (2008): Blue-Collar Blues: Is Trade to Blame for Rising U.S. Income Inequality?, Washington D.C.

Lemieux, T. (2006), Increasing Residual Wage Inequality: Composition Effects, Noisy Data, or Rising Demand for Skill?, American Economic Review 96(3), 461-498.

OECD (2007a): Economic Outlook No. 81, May 2007, Paris.

OECD (2007b): OECD Health Data 2007: Statistics and Indicators for 30 Countries, Paris.

OECD (2007c): Pensions at a Glance, Public Policies Across OECD Countries, Paris.

OECD (2007d): Social Expenditure Database (SOCX 2007), 1980-2003, Paris.

OECD (2007e): Main Economic Indicators, December, Paris.

OECD (2006a): Live Longer, Work Longer, Paris.

OECD (2006b): Education at a Glance, OECD Indicators 2006, Paris.

OECD (2005): China, Economic Surveys, Volume 2005/13, Paris. 
OECD (2002): China in the World Economy: The Domestic Policy Challenges, Paris.

Piketty, T. and E. Saez (2003): Income Inequality in the United States, 1913-1998, Quarterly Journal of Economics 118(1), 1-39.

Poirson, H. (2006): The Tax System in India, IMF Working Paper 06/93, Washington. Rybczynski, T.M. (1955): Factor Endowments and Relative Commodity Prices, Economica 22, 336-341.

Sachs, J.D. and H.J. Shatz (1996): U.S. Trade with Developing Countries and Wage Inequality, American Economic Review 86(2), 234-239.

Social Security Association (SSA) (2007): Social Security Programs Throughout the World: Asia and the Pacific, 2006, Washington D.C.

Social Security Association (SSA) (2006): Social Security Programs Throughout the World: The Americas, 2005, Washington D.C.

Timmer, M. T. van Moergastel, E. Stuivenwold, G. Ypma, M. O’Mahony and M. Kangasniemi (2007): EU Klems Growth and Productivity Accounts, Groningen Growth and Development Centre and NIESR London. http://www.euklems.net/

United Nations Population Division (UNPD)(2007): World Population Prospects: The 2006 Revision, New York.

U.S. Census Bureau (2008): Current Population Survey, 2007 Annual Social and Economic Supplement, Washington D.C.

U.S. Department of Labor (2007): Consumer Expenditures in 2005, U.S. Bureau of Labor Statistics Report 998, Washington.

World Bank (2007): World Development Indicators Database, Washington.

World Bank (2005): South Asia Pension Schemes for the Formal Sector, Finance and Private Sector Development Unit, Washington.

Wood, A. (1998): Globalization and the Rise in Labour Market Inequalities, Economic Journal 108, 1463-1482.

Valentinyi, A. and B. Herrendorf (2008): Measuring Factor Income Shares at the Sectoral Level, Review of Economic Dynamics 11, 820-835. 